\title{
Dynamic Connectedness of Asian Equity Markets
}




\section{WP/16/57}

\section{IMF Working Paper}

\section{Dynamic Connectedness of Asian Equity Markets}

by Roberto Guimarães-Filho

Gee Hee Hong

IMF Working Papers describe research in progress by the author(s) and are published to elicit comments and to encourage debate. The views expressed in IMF Working Papers are those of the author(s) and do not necessarily represent the views of the IMF, its Executive Board, or IMF management.

I N T E R N A T I O N A L M O N E T A R Y F U N D 


\title{
IMF Working Paper
}

Asia and Pacific Department

\section{Dynamic Connectedness of Asian Equity Markets \\ Prepared by Roberto Guimarães-Filho and Gee Hee Hong}

Authorized for distribution by Ranil Manohara Salgado

March 2016

\section{IMF Working Papers describe research in progress by the author(s) and are published to elicit comments and to encourage debate. The views expressed in IMF Working Papers are those of the author(s) and do not necessarily represent the views of the IMF, its Executive Board, or IMF management.}

\begin{abstract}
Understanding how markets are connected and shocks are transmitted is an important issue for policymakers and market participants. In this paper, we examine the connectedness of Asian equity markets within the region and vis-à-vis other major global markets. Using timevarying connectedness measures, we address the following questions: (1) How has connectedness in asset returns and volatilities changed over time? Do markets become more connected during crises periods? (2) Which markets are major sources and major recipients of shocks? Has there been a shift in terms of the net shock givers and shock receivers (directional connectedness over time)? Finally, we investigate the connectedness between China's equity markets and other countries' equity markets since August 2015 to highlight the growing importance of emerging market economies, particularly China, as sources of shocks.
\end{abstract}

JEL Classification Numbers: G1, F3

Keywords: financial spillovers, Asia financial integration, financial linkages, stock market, vector autoregression

Author's E-Mail Address: RGuimaraes@imf.org, GHong@imf.org 
This page intentionally left blank 


\section{Table of Contents}

Abstract
I. Introduction
II. Measures of Connectedness
III. Data
IV. Equity Returns and Volatilities Connectedness: The Evidence
$\quad$ A. Main Results
$\quad$ B. Case Study: China Financial Connectedness to the Rest of the World in August
$\quad 2015$
$\quad$ C. Robustness Checks_ts
V. Concluding Remarks
References

\section{Tables}

Table 1. Descriptive Statistics for Asset Return ___ 9

Table 2. Descriptive Statistics for Daily Volatility___

\section{Figures}

Figure 1. Time-varying Connectedness of Equity Returns and Volatilities____ 14

Figure 2. Net Connectedness of Equity Returns: Japan, China, and Korea ___

Figure 3. Dynamic Net Connectedness: Advanced Economies vs. Emerging Markets___ 16

Figure 4. Net Directional Connectedness Index from China to Selected Countries __ 17

Figure 5. Net Connected Index from China

Figure 6. Connectedness Index - Equity Market Spillovers from China___

Figure 7. Total Connectedness Index: China to Hong Kong SAR __ 20

Figure 8. Total Connectedness Index by Sector: China to Hong Kong SAR ___ 21

\section{Appendix}

Appendix Table 1. Equity Returns Connectedness (Time Period: 06/30/2002-

$$
\text { 11/01/2015) }
$$

Appendix Table 2. Equity Volatilities Connectedness (Time Period: 06/30/2002-

$11 / 01 / 2015) \ldots$

Appendix Figure 3. Dynamic Connectedness (Equity Returns and Volatility) __ 27

Appendix Figure 4. Dynamic Directional Connectedness of Equity Returns (Contributions to Others $\underline{28}$

Appendix Figure 5. Dynamic Directional Connectedness of Equity Volatility (Contributions to Others) $\underline{29}$ 
Appendix Figure 6. Dynamic Directional Connectedness of Equity Returns (Contributions from Others)

Appendix Figure 7. Dynamic Directional Connectedness of Equity Volatility (Contributions from Others) $\underline{31}$

Appendix Table 8 Dynamic Net Connectedness of Equity Return $\underline{32}$ Appendix Table 9. Dynamic Net Connectedness of Equity Volatility $\underline{33}$ Appendix Table 10. Robustness Check: Dynamic Connectedness (Different Forecast Horizons) $\underline{34}$ 


\section{INTRODUCTION}

Understanding how shocks are transmitted across markets is a critical issue for policymakers and market participants in highly connected economies. During times of crisis the degree of market interdependence comes to the forefront of discussions and market monitoring. For example, during the Asian financial crises of 1997-98, shocks from Thailand brought ripple effects to neighboring markets, and subsequently to other markets across the globe. During the global financial crisis of 2008-09, shocks emanating initially from the United States reached nearly all corners of the global economy albeit at varying degrees, reflecting not only the sheer size and significance of the initial shock, but also the powerful transmission mechanism, particularly trade and financial linkages.

Since the Asian financial crisis, policymakers in Asia have sought for a greater financial cooperation and integration within the region. These efforts include regional liquidity support arrangements through the Chiang Mai Initiative Multilateralization and more recently, the Association of Southeast Asian Nations (ASEAN) is outlining guidelines to foster regional capital market integration (Almekinders et al. 2015). Despite these efforts, financial integration within the region and with the rest of the world still lags that of trade integration (IMF 2015, Cheng et al. 2015). According to the IMF 2015, the degree of financial integration within Asia has increased but remains relatively low - only about 20 percent to 30 percent of cross-border portfolio investment and bank claims are intraregional, while more than half of Asia's merchandise exports and imports go to, or originate from, elsewhere within the region. ${ }^{1}$ The relatively high degree of 'home bias' as well as regulatory policies, such as foreign asset holdings and barriers to foreign bank entry, explain to some extent the low degree of intra-regional financial integration.

In addition to their increasing economic importance, recent events in financial markets also suggest that emerging market economies in Asia can become a major source of financial shocks that may be transmitted widely, including to advanced economies (AEs). The spillovers from China's stock market volatility onto other stock markets during August of 2015 are an example of the growing importance of China's role as a conduit and source of financial spillovers. In particular, spillovers have been sizable after the Chinese stock market fell sharply by 8.5 percent on August 24, 2015, following the announcement of change in the Renminbi (RMB) regime and the subsequent drop in the currency value against the U.S. dollar. During this episode, A-shares in the Shanghai Stock Exchange lost one third of their market value. The subsequent plunge in Asia equity markets - Hong Kong, Korea and

\footnotetext{
${ }^{1}$ According to International Trade Statistics (World Trade Organization, 2014), 53.3 percent of total Asia's merchandise flows end up in Asia. This ratio of intra-regional trade flows is the second highest, following Euro area where nearly two thirds $(68.8 \%)$ of its trade flows originates from the region.
} 
Malaysia in particular - was significant. Furthermore, it also had ripple effects affecting U.S. and European markets.

Financial integration within Asia, while not as strong as trade integration, has been on the rise. With the greater emphasis on intraregional financial integration initiatives in Asia, it is important to understand how the interdependence of financial markets across Asian economies has evolved.

In this paper, we examine the connectedness of Asian equity markets within the region and with other major global markets by quantifying the contribution of shocks from Asian equity markets to other countries' at different points in time. Against this backdrop, we address the following questions in this paper: (1) how has the connectedness in equity returns and volatilities changed over time? Do equity markets become more connected during crises periods? (2) Which equity markets are major sources and major recipients of shocks? Has there been a shift in terms of the net shock givers and shock receivers (directional connectedness over time)? Finally, we investigate how China has emerged as an important source (or transmitter) of financial shocks to other economies inside and outside of the region, including after the heightened stock market volatility since the summer of 2015.

Why the focus on Asia?

Since the Asian financial crisis, the rise of emerging market economies in the global economy, particularly Asian economies, has been one of the major changes in the global economic and financial landscapes. China's economy is a case in point: it currently accounts for about one-third of global growth. Other emerging market economies in Asia (and elsewhere) have also become, to varying degrees, important players in global trade and finance. In terms of the results discussed below, the growing role of China and other emerging Asian economies in the global economy suggests that most likely these economies have become important sources and conduits of financial shocks.

The paper's main findings suggest that Asia, as a region, plays an important role as a conduit of financial shocks. The main results are as follows:

- There has been a substantial increase in the aggregate equity return and volatility connectedness indexes since the global financial crisis (Figure 1). The increases in the indexes have been nearly across the board, with both advanced and emerging market economies experiencing greater "to" and "from" spillovers (implying greater connectedness).

- Since the global financial crisis, the net connectedness indexes of both return and volatilities exhibit a distinct pattern between advanced economies and emerging markets: advanced economies have increasingly become net 'receiver' of shocks, 
while emerging market economies, particularly China, ASEAN-5 (Indonesia, Malaysia, the Philippines, Singapore, and Thailand), and Korea have increasingly become the sources of shocks (see Figure 2 for a selection of sample countries).

- The decrease in the net connectedness indexes for advanced economies since the global financial crisis has been driven by both the decline in the contribution to others and the increase in contributions from other countries. Meanwhile, the rise in net connectedness in emerging markets since the global financial crisis has been driven by the increase in the contribution to other economies, suggesting that fluctuations in emerging markets' equity prices have been exerting more influence over global markets.

- Finally, the increase in the net return and volatility connectedness indexes in most Asian emerging economies is consistent with the trend of growing intra-regional financial integration. Regional financial integration has deepened since the global financial crisis, as foreign banking claims of euro area banks in the emerging and developing Asia and Pacific Region have declined since 2008, and have been replaced by the expansion of Japanese and Chinese banks. ${ }^{2}$

\section{Measures of Connectedness}

In this paper we use a measure of connectedness across equity markets in different countries developed by Diebold and Yilmaz $(2009,2012,2014)$ to assess the degree of connected in Asian equity markets. ${ }^{3}$ The connectedness measure developed by Diebold and Yilmaz (previously referred to as the spillover index, 2009) is based on dynamic variance decompositions from vector autoregression (VAR) applied to asset returns and volatilities. For each asset $i$, in an N-variable VAR, the measure of connectedness is the sum of the shares of its forecast error variance coming from shocks to asset $j$, for all $j \neq i$. In this paper, we follow Diebold and Yilmaz (2012), where the shocks are decomposed using generalized vector autoregressive framework (Koop, Pesaran, and Potter 1996, Pesaran and Shin 1998). The benefit of the generalized VAR framework, unlike other orthogonalization schemes such as the Cholesky decompositions, is that the forecast-error variance decompositions are invariant to the ordering of the variables in the VAR. ${ }^{4}$ In addition, instead of attempting to

\footnotetext{
${ }^{2}$ IMF, Chapter 2: "International Banking After the Crisis: More Local and More Safe", Global Financial Stability Report (April 2015).

${ }^{3}$ See IMF, Chapter 3: "The Growing Importance of Financial Spillovers from Emerging Market Economies", Global Financial Stability Report, upcoming (April 2016) who applies the same methodology to analyze the connectedness of emerging market economies including those outside of Asia.

${ }^{4}$ Diebold and Yilmaz (2009) use the Cholesky-factor identification to orthogonalize the shocks. The authors note that in Diebold and Yilmaz (2014) the difference in the connectedness measure with the variable orderings
}

(continued...) 
orthogonalize shocks, the generalized approach allows for correlated shocks.Consider a standard N-variable VAR(p) framework, where $\mathrm{x}_{\mathrm{t}}=\sum_{\mathrm{i}=1}^{\mathrm{p}} \Phi_{\mathrm{i}} \mathrm{x}_{\mathrm{t}-\mathrm{i}}+\varepsilon_{\mathrm{t}}$, where $\Sigma$ is the variance of error terms, and the error term is a vector of independently and identically distributed disturbances. One can rewrite the system into a moving average representation as $\mathrm{x}_{\mathrm{t}}=\sum_{\mathrm{i}=0}^{\infty} \mathrm{A}_{\mathrm{i}} \varepsilon_{\mathrm{t}-\mathrm{i}}$ where $\mathrm{A}_{\mathrm{i}}=\sum \Phi_{\mathrm{j}} \mathrm{A}_{\mathrm{i}-\mathrm{j}}$ and $\mathrm{j}=1, \ldots, \mathrm{p}$. The H-step-ahead forecast error variance decompositions $\left(\theta_{\mathrm{ij}}^{\mathrm{g}}(\mathrm{H})\right)$, using the generalized vector autoregressive framework (hereafter, generalized VAR) is defined as follows:

$$
\theta_{\mathrm{ij}}^{\mathrm{g}}(\mathrm{H})=\frac{\sigma_{\mathrm{ii}}^{-1} \sum_{\mathrm{h}=\mathrm{o}}^{\mathrm{H}-1}\left(\mathrm{e}_{\mathrm{i}}^{\prime} \mathrm{A}_{\mathrm{h}} \sum \mathrm{e}_{\mathrm{j}}\right)^{2}}{\sum_{\mathrm{h}=0}^{\mathrm{H}-1}\left(\mathrm{e}_{\mathrm{i}}^{\prime} \mathrm{A}_{\mathrm{h}} \sum \mathrm{A}_{\mathrm{h}}^{\prime} \mathrm{e}_{\mathrm{i}}\right)}
$$

where $\Sigma$ is the variance matrix for the error term for the VAR, $\sigma_{\mathrm{ii}}$ is the standard deviation of the error term for the $i$ th equation and $\mathrm{e}_{\mathrm{i}}$ is the selection vector with one for the $i$ th element and zero otherwise. Since the generalized VAR allows for correlated shocks the sum of the elements of each contribution of the variance decomposition may not be equal to 1 . Then, following Diebold and Yilmaz (2012), each forecast error variance decomposition is normalized by the row sum as:

$$
\tilde{\theta}_{\mathrm{ij}}^{\mathrm{g}}(\mathrm{H})=\frac{\theta_{\mathrm{ij}}^{\mathrm{g}}(\mathrm{H})}{\sum_{\mathrm{j}=1}^{\mathrm{N}} \theta_{\mathrm{ij}}^{\mathrm{g}}(\mathrm{H})}
$$

\section{$\underline{\text { Total Connectedness }}$}

Total connectedness is the sum of cross-variance shares, which are the fractions of the Hstep-ahead error variances in forecasting $x_{i}$ due to shocks to $x_{j}$. Using the normalized forecast error variance decomposition, $\tilde{\theta}_{\mathrm{ij}}^{\mathrm{g}}(\mathrm{H})$, total connectedness measure, $\mathrm{S}^{\mathrm{g}}(\mathrm{H})$ is defined as follows:

$$
S^{g}(H)=\frac{\sum_{i, j=1, i \neq j}^{N} \tilde{\theta}_{i j}^{g}(H)}{\sum_{i, j=1}^{N} \tilde{\theta}_{i j}^{g}(H)} 100
$$

matter in a qualitatively insignificant way in total connectedness, while the directional connectedness may be more sensitive to variable orderings. 


\section{$\underline{\text { Directional Connectedness }}$}

Directional connectedness is a measure of the connectedness that captures the shocks received by vector $i$ from all other vectors $j$. Similarly, one can define the directional connectedness from vector $i$ to all other vectors.

The first directional connectedness (vector $i$ from all other vectors) is measured as follows:

$$
S_{i \cdot}^{g}(H)=\frac{\sum_{j=1, j \neq i}^{N} \tilde{\theta}_{i j}^{g}(H)}{\sum_{j=1}^{N} \tilde{\theta}_{i j}^{g}(H)} 100
$$

The second directional connectedness (shocks by vector $i$ to all other vectors) is similarly measured as follows:

$$
S_{\cdot i}^{g}(H)=\frac{\sum_{j=1, j \neq i}^{N} \tilde{\theta}_{j i}^{g}(H)}{\sum_{j=1}^{N} \tilde{\theta}_{j i}^{g}(H)} 100
$$

\section{$\underline{\text { Net Connectedness }}$}

Finally, using the directional connectedness measures, one can obtain the net connectedness, which is simply the difference between the volatility shocks transmitted to and volatility shocks transmitted from all other markets.

$$
\mathrm{S}_{\mathrm{i}}^{\mathrm{g}}(\mathrm{H})=\mathrm{S}_{\cdot \mathrm{i}}^{\mathrm{g}}(\mathrm{H})-\mathrm{S}_{\mathrm{i}}^{\mathrm{g}}(\mathrm{H})
$$

\section{Dynamic Connectedness}

How does the estimated connectedness index change over time? Does connectedness increase (or decrease) during the periods of high uncertainty, such as during financial crises? To shed light on these questions and to capture the time-varying nature of the connectedness, one can also compute the connectedness measure for a specific time-horizon. Diebold and Yilmaz $(2009,2012,2014)$ use a rolling-window methodology using the same measures described above to address this question. 


\section{DATA}

The main underlying data are daily nominal local-currency stock market indexes from January 1996 to October 2015, taken from Haver Analytics. The sample includes 13 Asian economies (Australia, China, Hong Kong SAR, India, Indonesia, Japan, Korea, Malaysia, New Zealand, the Philippines, Singapore, Taiwan Province of China, Thailand), four advanced countries (United States, United Kingdom, Germany, France) and three emerging markets from other regions (Brazil, Mexico, Turkey). Additional estimations were also done including Europe and South Africa (and excluding Germany and France) from June 24, 2002 (with South Africa data available after this date).

First, for asset returns, we compute the change in the log-price, Friday-to-Friday (nominal return). ${ }^{56}$ Descriptive statistics for nominal return is in Table 1.

Second, we calculate the volatility following Parkinson (1980) and Diebold and Yilmaz (2012) using daily high and low prices. First, we calculate the daily variance of market $i$ on day $t$, the daily variance as follows:

$$
\widetilde{\sigma_{1 t}^{2}}=0.361\left[\ln \left(\mathrm{P}_{\mathrm{it}}^{\max }\right)-\ln \left(\mathrm{P}_{\mathrm{it}}^{\min }\right)\right]^{2}
$$

where $\mathrm{P}_{\mathrm{it}}^{\max }$ is the maximum (high) price of market $i$ on day $t$, and $\mathrm{P}_{\mathrm{it}}^{\min }$ is the daily minimum (low) price. Then, the corresponding estimate of the annualized daily volatility (percent standard deviation) is given by:

$$
\widehat{\sigma_{1 t}}=100 \sqrt{365 \cdot \widetilde{\sigma_{1 t}^{2}}}
$$

Descriptive statistics for daily volatility is in Table 2.

\footnotetext{
${ }^{5}$ We can extend the analysis to real return, by assuming that the weekly inflation rate is constant within the month and take the $1 / 4^{\text {th }}$ power of the monthly inflation rate as a weekly inflation rate. The real weekly return will be (nominal return/weekly inflation rate)-1.

${ }^{6}$ With daily data and other high frequency data, the temporal pattern of trade should be considered carefully to ensure that findings are not due to the fact that some markets start trading before others. The time zone difference may confound the analysis of spillovers as it complicates the interpretations of the directional and causal relationships of the movements of markets with different trading periods. Several approaches have been introduced to address this issue, including two-day averaging of daily returns and use of weekly returns (see, for instance, Diebold and Yilmaz (2009) and Forbes and Chinn (2003)). In this paper, as discussed below, the results are robust after several robustness checks, including different time horizons and different variable orderings in the Cholesky decompositions of returns.
} 
Table 1. Descriptive Statistics for Weekly Asset Returns

mean

median

st.dev

skewness

kurtosis

\begin{tabular}{rrrrrr} 
JPN & AUS & HKG & KOR & IDN & MYS \\
\hline 0.000 & 0.001 & 0.001 & 0.001 & 0.002 & 0.001 \\
0.001 & 0.003 & 0.003 & 0.003 & 0.004 & 0.002 \\
0.031 & 0.020 & 0.034 & 0.041 & 0.035 & 0.029 \\
-0.973 & -1.133 & -0.437 & -0.492 & -0.275 & 0.122 \\
10.423 & 10.627 & 6.385 & 7.301 & 5.095 & 14.427
\end{tabular}

mean

median

st.dev

skewness

kurtosis

\begin{tabular}{rrrrrr} 
PHL & THA & IND & USA & GBR & FRA \\
\hline 0.001 & 0.000 & 0.002 & 0.001 & 0.001 & 0.001 \\
0.003 & 0.003 & 0.004 & 0.002 & 0.002 & 0.003 \\
0.034 & 0.038 & 0.039 & 0.025 & 0.024 & 0.029 \\
-0.557 & -0.276 & -0.431 & -0.742 & -1.109 & -0.901 \\
8.572 & 7.952 & 7.955 & 9.117 & 13.668 & 9.495
\end{tabular}

mean

median

\begin{tabular}{rrrrrr} 
DEU & CAN & BRA & MEX & TUR & TUR \\
\hline 0.001 & 0.001 & 0.003 & 0.003 & 0.005 & 0.000
\end{tabular}

st.dev

0.005

0.003

0.005

0.004

0.006

0.001

skewness

0.033

$0.024 \quad 0.044$

0.034

0.055

0.031

kurtosis

7.760

$-0.933$

$-0.573$

$-0.137$

$-0.120$

$-0.471$

Sources: Haver Analytics and IMF staff calculations

Table 2. Descriptive Statistics for Daily Volatility

mean
median
st.dev
skewness
kurtosis

mean
median
st.dev
skewness
kurtosis

\begin{tabular}{rrrrrrr} 
JPN & AUS & HKG & KOR & TWN & IDN & MYS \\
\hline 17.33 & 11.80 & 17.49 & 21.18 & 16.40 & 19.42 & 13.45 \\
14.86 & 9.81 & 14.40 & 17.39 & 13.78 & 15.38 & 9.56 \\
10.95 & 8.15 & 12.03 & 14.42 & 10.34 & 14.75 & 13.41 \\
0.27 & 0.38 & 0.30 & -0.76 & -1.13 & 0.14 & 2.97 \\
21.06 & 22.83 & 22.61 & 9.37 & 5.81 & 18.04 & 77.43
\end{tabular}

\begin{tabular}{rrrrrrr} 
PHL & THA & CHN & IND & USA & GBR & FRA \\
\hline 17.33 & 11.81 & 17.48 & 21.18 & 16.41 & 19.42 & 13.45 \\
14.86 & 9.81 & 14.39 & 17.39 & 13.78 & 15.39 & 9.56 \\
10.95 & 8.16 & 12.03 & 14.42 & 10.33 & 14.75 & 13.43 \\
0.28 & 0.38 & 0.30 & -0.76 & -1.12 & 0.14 & 2.96 \\
21.08 & 22.81 & 22.60 & 9.37 & 5.83 & 18.04 & 77.01
\end{tabular}


mean

median

st.dev

skewness

kurtosis

\begin{tabular}{rrrrrr} 
DEU & CAN & BRA & ARG & MEX & EU \\
\hline 17.33 & 11.81 & 17.48 & 21.19 & 16.43 & 19.41 \\
14.86 & 9.81 & 14.37 & 17.39 & 13.79 & 15.39 \\
10.95 & 8.16 & 12.03 & 14.42 & 10.33 & 14.75 \\
0.27 & 0.37 & 0.30 & -0.76 & -1.12 & 0.14 \\
21.06 & 22.78 & 22.58 & 9.37 & 5.84 & 18.06
\end{tabular}

Sources: Haver Analytics and IMF staff calculations 


\section{Equity RETURNS AND Volatilities CONNECTEDNESS: The EVIDENCE}

\section{A. Main Results}

According to our baseline estimations, there has been a substantial increase in aggregate equity return and volatility connectedness since the global financial crisis (Figure 1). This is followed by a mild decrease in recent years, probably reflecting the fact that spillovers rose sharply in the aftermath of the global financial crisis. During the global financial crisis, connectedness rose steeply due to the synchronized plunge of asset markets around the world, highlighting again the magnitude and impact of the initial shocks coming from equity markets (and other asset markets more generally). This is true for both equity returns and volatilities.

The results reported below in this section are based on generalized impulse response functions (invariant to the ordering of variables in the VAR) and the VARs are estimated with four lags, and the connectedness is calculated for a 10-week horizon. In addition, the estimations also yield the direction connectedness, i.e., the net contributions (to minus from) of an economy to other economies relative to the contributions of others' to its asset price fluctuations. For instance, in the sample examined here, this approach enables us to measure how much of Malaysia's asset returns are explained by the shocks originating from the rest of the world in total, but also from a specific economy (say, China), and vice versa. This feature of the connectedness measures considered here have a "spillover" flavor and complements standard analyses of the impact of financial shocks on real and financial variables. Finally, using rolling-windows estimation, one can also understand the timevarying intensity of spillovers and the behavior of spillovers during crisis and non-crisis periods. ${ }^{7}$ The baseline results are based on a 200-week window, but the results are robust to different lags (eight months), forecasting horizons (15, 20 weeks) and windows (100 weeks).

Diebold and Yilmaz (2009) highlight the difference between equity returns and volatilities connectedness. Unlike dynamic returns connectedness measures which generally display smooth upward trending behavior without bursts or spikes, dynamic volatilities connectedness measures display spikes, along with the trend. Prior to the global financial crisis, we do observe similar patterns for Asian equity markets - Figure 1 illustrates that the connectedness measure for equity volatility has more spikes, while the returns connectedness measure is smoother and trends upwards. During the global financial crisis, both connectedness measures peaked, consistent with the sizable shocks (and their fast transmission) across markets and regions in our sample. Appendix Figures 3-9 show the

\footnotetext{
${ }^{7}$ We can extend the analysis to real returns, by assuming that the weekly inflation rate is constant within the month and take the $1 / 4^{\text {th }}$ power of the monthly inflation rate as a weekly inflation rate. The real weekly return will be (nominal return/weekly inflation rate)-1.
} 
dynamic total and net connectedness for each economy for both equity returns and volatilities.

Figure 1. Time-varying Connectedness of Equity Returns and Volatilities

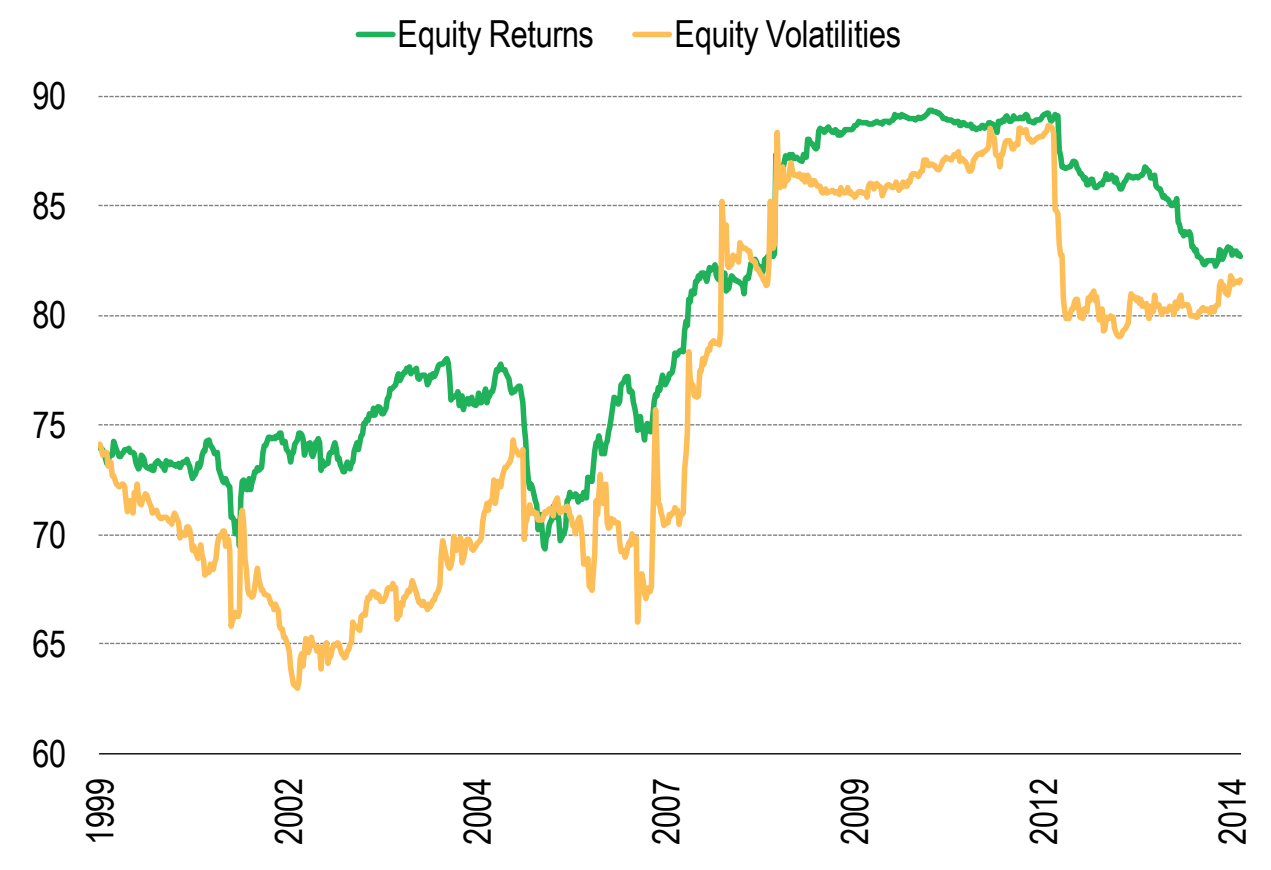

Sources: Haver Analytics and IMF staff calculations

Another important finding that is pertinent to Asia is the growing importance of emerging market economies as net shock givers and less as net shock receivers. This is consistent with the view that EMs are increasingly relevant to global finance as sources and conduits of financial shocks. Figure 2 shows that net connectedness from China and Korea is on the rise, while the net connectedness from Japan is declining in the past couple of years. Furthermore, when averaging the index by groups of economies depending on their economic development (AEs vs. EMs), we confirm that the connectedness measures have declined in AEs, while the opposite is true for the EMs in Asia (Figure 3).

Why is financial connectedness rising in EMs, particularly EMs in Asia, while declining in AEs?

First, direct financial linkages between EMs and other economies have increased, with the growing weight of EMs in global portfolios. IMF (2014b) show that the holdings of EM FDI and portfolio equity reached more than 15 percent of AE's portfolio abroad, and 15 percent of AE's GDP in 2012. While the direct cross-border lending has declined since the global financial crisis, global banks are integrated in AEs and EMs through large subsidiaries and branches networks. Second, economic developments in major EMs have greater influence on other countries and asset markets through trade linkages. The greater importance of EMs in 
the global economy has translated into the greater attention to these market developments by global investors. Glick and Hutchinson (2013) show that Asian stock markets have become more correlated with the Chinese stock market since the global financial crisis than bond markets. They note that international investors are increasingly more 'attentive' to China's role as a destination of equity finance and such behaviors have translated into the greater correlation of equity price changes between China and other Asian countries. Third, an important channel of how EMs can affect global asset markets is through commodity prices. The ongoing rebalancing and slowdown in China, in particular, has been one of the drivers of major commodity prices. News about economic prospects in China originating in China's equity markets are then transmitted to commodity price and equity prices of other EMs, including commodity importers. In this way, equity prices act as a conduit of shocks across broader global markets.

Figure 2. Net Connectedness of Equity Returns: Japan, China and Korea

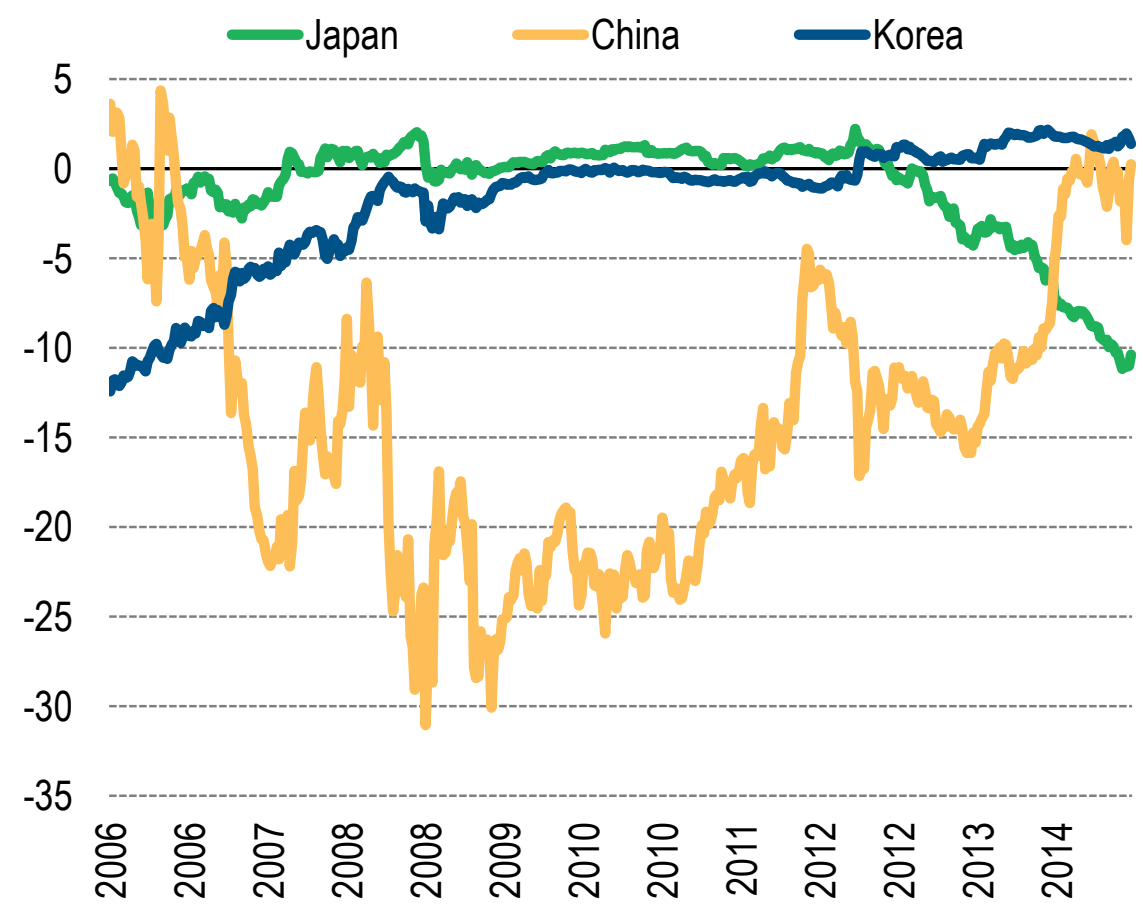

Sources: Haver Analytics and IMF staff calculations 
Figure 3. Dynamic Net Returns Connectedness: Advanced Economies vs. Emerging Markets

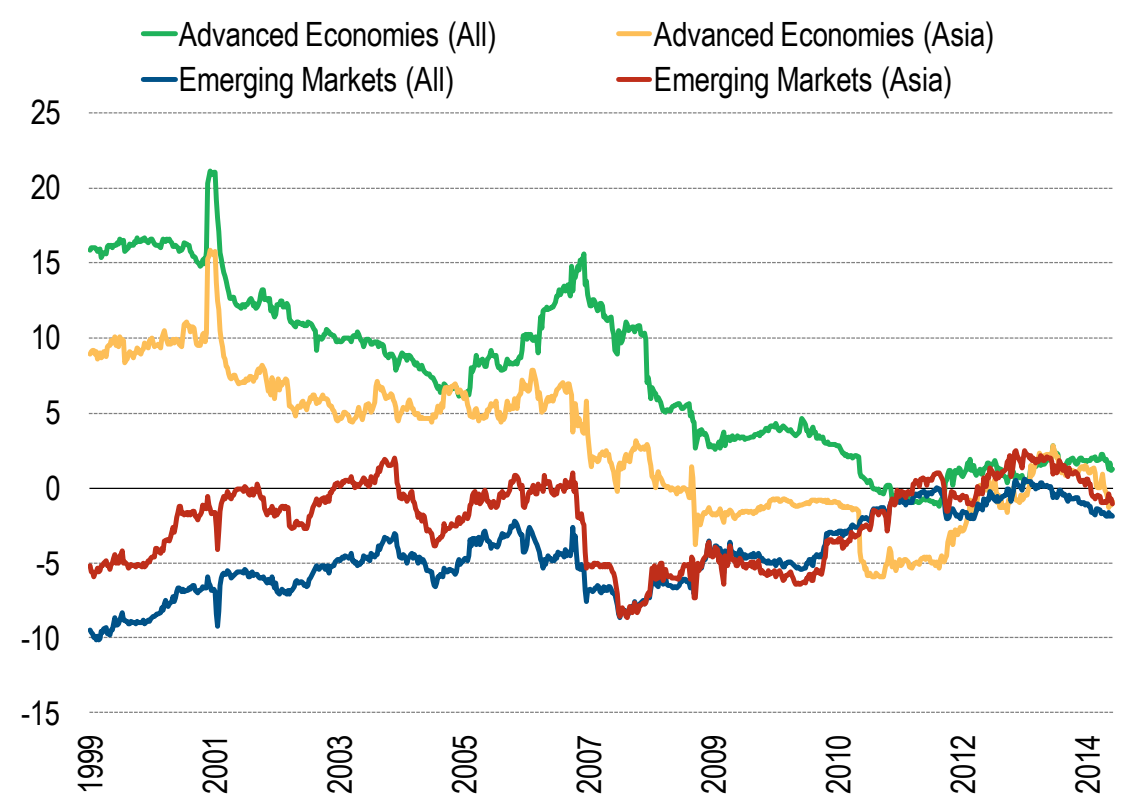

Sources: Haver Analytics and IMF staff calculations

\section{B. Case Study: China Financial Connectedness to the Rest of the World and Hong Kong SAR since August 2015}

Recent movements in China's equity markets have generated ripple effects across global stock markets, affecting not only Asian equity markets, but also U.S. and European financial markets. To what extent do China's equity market movements "explain" other equity markets returns?

Our analysis confirms the growing importance of China as the net source of financial shocks. Figure 4 shows that China's equity returns contributed to a larger share of the movements in other equity markets in 2015 and into early 2016, especially as news originating from China impacted its own domestic market as well as markets worldwide. This is in sharp contrast to Japan, whose contribution to other equity market movements has been steadily declining over the same period. Furthermore, China's equity market, on a net basis, contributes far more in terms of shocks to other markets than it receives starting from the second half of 2015. The increased contribution of China's equity returns to other markets is also farreaching, with the steep increase observed for both advanced economies, including systemically-important ones such as the United States and euro area, and emerging economies (Figure 4). Furthermore, the sharp increase in CI since mid-2015 (relative to China's equity market boom during mid-2014 to mid-2015) suggests that 'contagion' effects - instead of direct financial linkages - could be also at play. 
The net connectedness index (CI) from China to other equity markets has increased sharply since the second half of 2015. Figure 5shows that the average CI has increased since the global financial crisis in 2008 for most of the countries. In some cases, there is also a sharp rise in the CI since the second of 2015. Compared to the "taper tantrum" episode (May-July 2013), the steep increase in the connectedness index is much more pronounced in recent months. During the taper tantrum the directional CI (from China) stayed relatively stable for nearly all economies considered.

Figure 4. Net Directional Returns Connectedness Index from CHN to Selected Countries

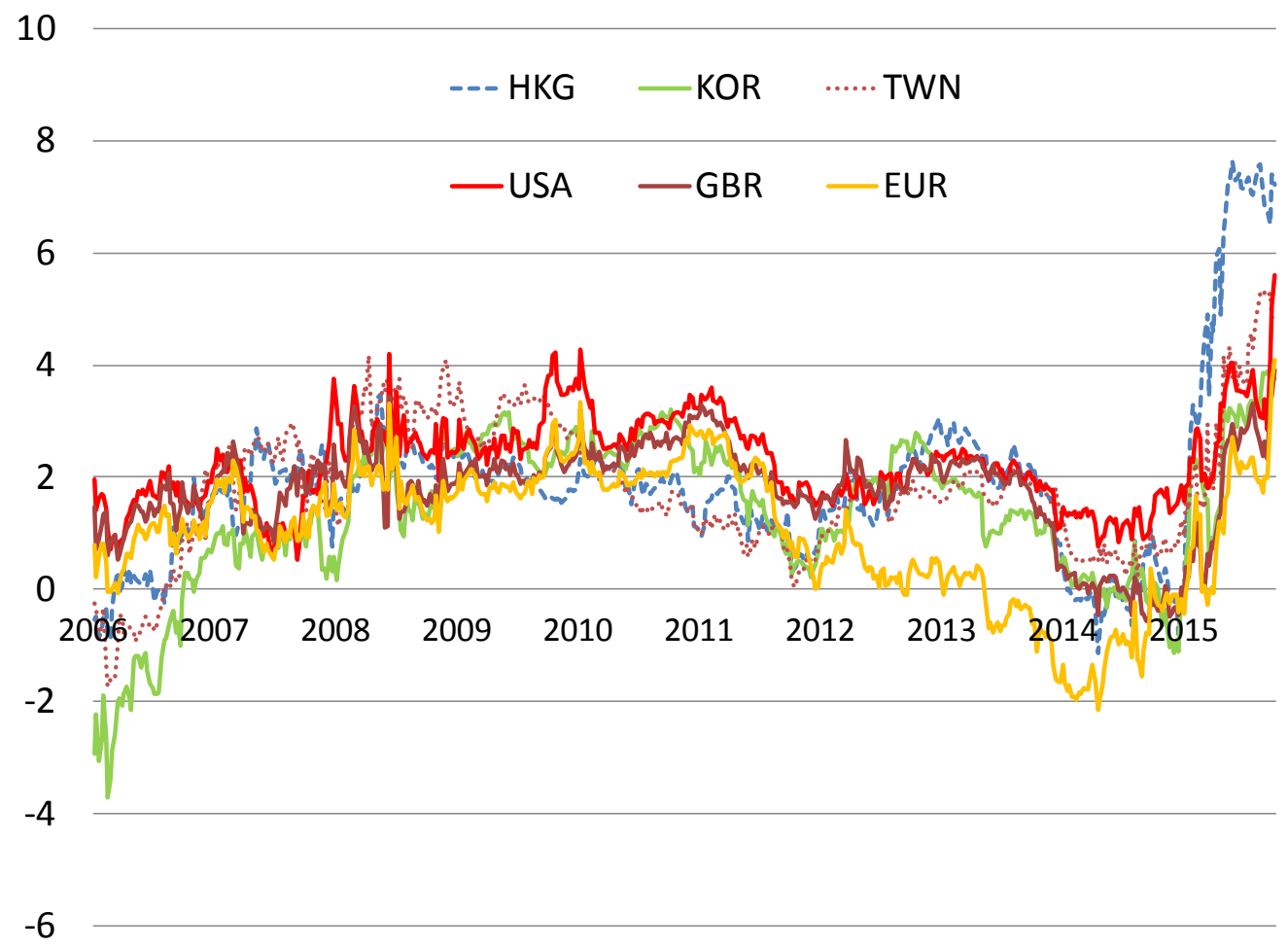


Figure 5. Net Connectedness Index from China

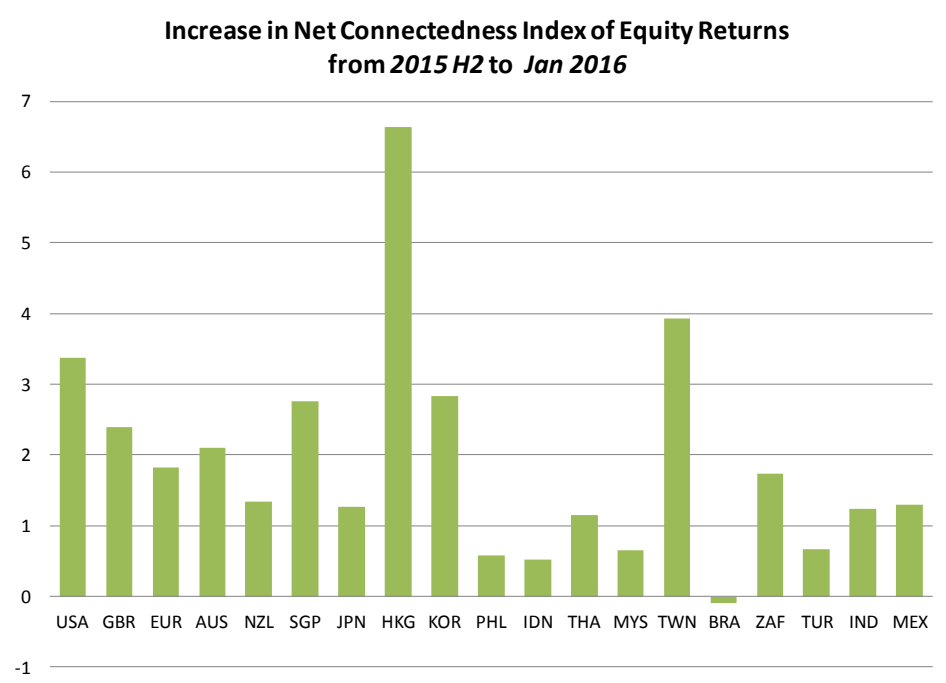

While financial integration in Asia has generally lagged trade integration, financial ties between Hong Kong SAR and China are a regional exception. Hong Kong SAR has served as a regional financial hub for Asia, and its ties to China have also increased significantly during the last decade or so, especially as China started liberalizing its financial markets and opening its financial account. Several initiatives (e.g., Connect scheme) may have boosted financial integration, while at the same time creating new channels for transmission of volatility and financial stress.

To understand how the interdependence of financial markets across the mainland and Hong Kong SAR has evolved over time, we apply the connectedness index to quantify the timevarying contribution of shocks from mainland China (and other markets) to Hong Kong SAR's equity returns and volatilities. The contribution to Hong Kong SAR's equity return (volatility) in the connectedness index is based on impulse response functions from estimated VARs. As in the preceding analysis, the VARs are estimated with daily data and have four lags, and the spillovers are calculated for a 10-week horizon. Rolling-window estimations are also used to calculate the time-varying intensity of the connectedness index and the behavior of spillovers during crisis and non-crisis periods. ${ }^{8}$ The sample period covers June 2002 August 2015, and the connectedness index is also calculated for sectoral indexes for a shorter sample covering February 2005-August 2015. The following indexes are used: Dow Jones Shanghai (China), Hang Seng Index (Hong Kong SAR), and Hang Seng Composite Industry Index (Hong Kong SAR) for sectoral market indexes (Haver Analytics). Finally, the VAR

\footnotetext{
${ }^{8}$ The baseline results are based on a 200 -week window, but the results are robust to different lags (eight months), forecasting horizons (15, 20 weeks) and windows (100 weeks). The estimations also yield directional CI, i.e., the net contributions (to minus from) of the Mainland to Hong Kong SAR minus the contributions of Hong Kong SAR to the Mainland's equity returns (volatilities).
} 
comprises asset returns and volatilities for 20 economies, including 13 Asian economies, and also controls for a few global factors that can affect equity returns and volatilities (global oil prices, U.S. VIX, and Citi Surprise indexes as a proxy for broader economic activity).

The results suggest that interlinkages between mainland China and Hong Kong SAR equity markets are strong and have been growing over time (Figure 5). Given the size of China's economy, it is not surprising that developments in China's financial markets have become increasingly more important for Hong Kong SAR (as well as the global economy). But some of the findings stand out:

- $\quad$ First, average connectedness (which measures the gross spillovers from China to other economies) shows that China's equity markets explain a larger share of Hong Kong SAR's equity returns (and volatility) than other economies. The other main regional financial center in the region, Singapore, has an average connectedness with the Mainland that is similar to that of Malaysia and Korea (Figure 6).

\section{Figure 6. Connectedness Indexes from China to Selected countries (May 2006 - August 2015)}

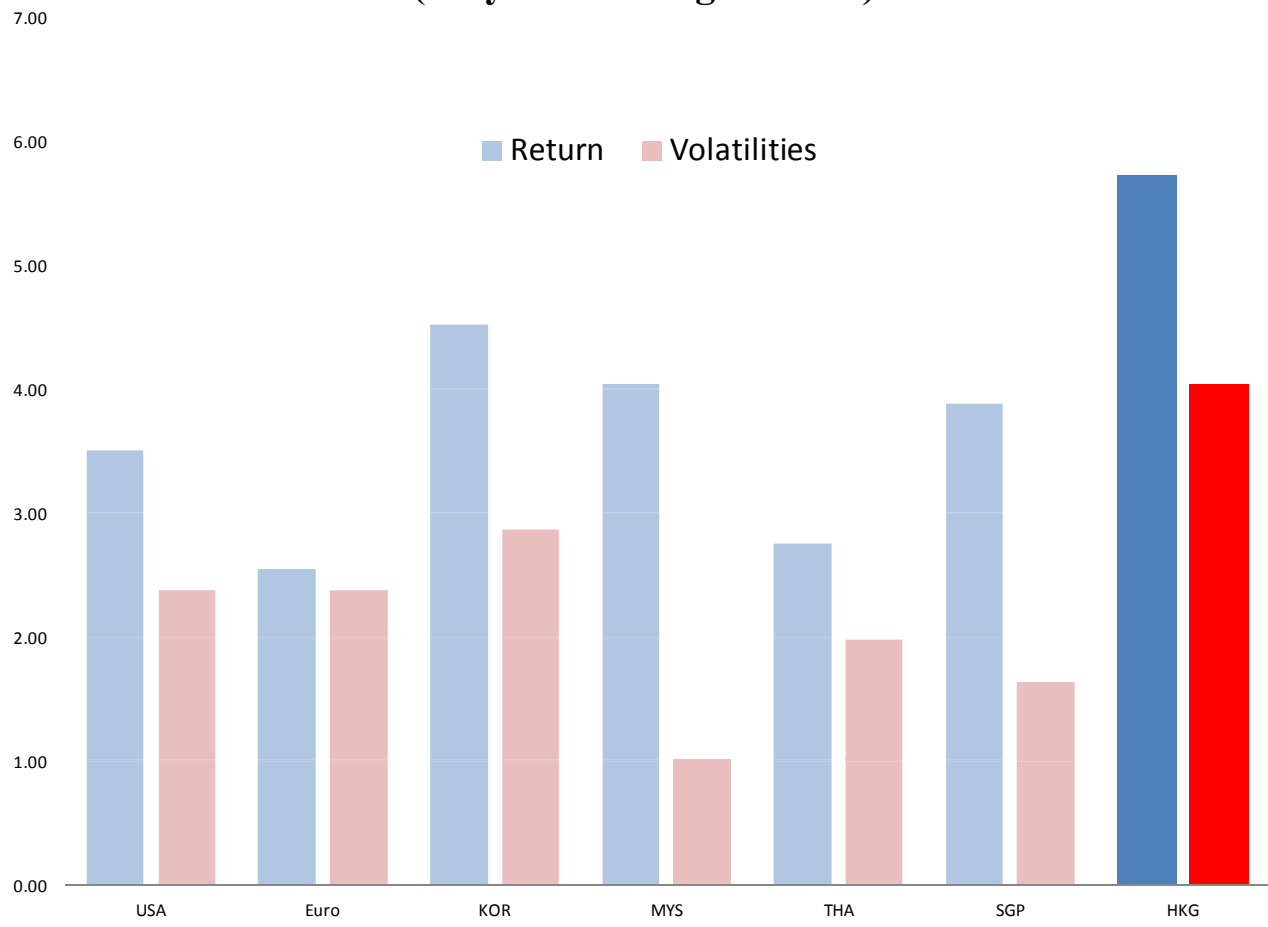

Sources: Haver Analytics and IMF staff calculations

- $\quad$ Second, financial connectedness between China and Hong Kong SAR has increased sharply over the last decade or so, consistent with trade integration and likely a symptom of greater financial integration (evidenced by inter alia, the volume of 
cross-border loans and equity listings, see Figure 7). In terms of the CI, equity market spillovers from China to Hong Kong SAR has risen sharply (both returns and volatilities). The return CI has been on the rise (with a spike in late 2014, which may be due to the market connectedness in November), while the volatility CI reached a peak in 2011. Interestingly, net spillovers from China to Hong Kong SAR equity volatility (not shown here) have been negative, suggesting that China's stock market has also been hit by shocks from Hong Kong SAR stock market, consistent with the latter's regional financial center status. 
Figure 7.Total Connectedness Indexes: China to Hong Kong SAR

12

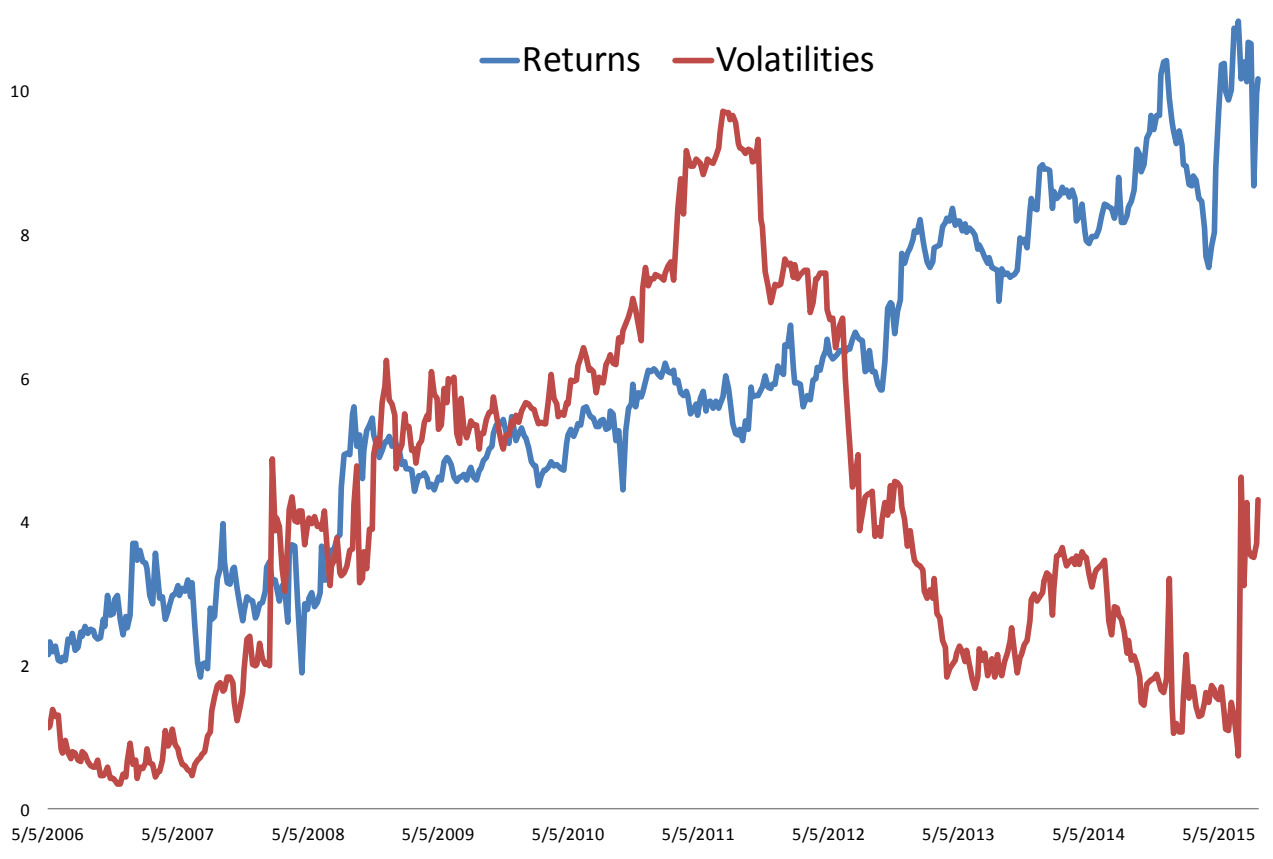

Sources: Haver Analytics and IMF staff calculations

- $\quad$ The increase in connectedness between China's equity market and Hong Kong SAR's stock market appears to be broad-based, affecting several key sectors. However, there is considerable sectoral heterogeneity, possibly reflecting differences in the real/operational linkages with Mainland China. Financials, properties and construction and consumer goods have seen a sharper rise in their connectedness with the Mainland, as measured by the CI, while information and technology sector also seems to have experienced a noticeable, albeit less drastic increase (Figure 8).

Financials and property and construction have also decoupled from the other sectors, first from information and technology, and more recently from consumer goods. It is possible that the rise in the CI for these sectors reflects real economic linkages. In the case of certain other sectors, for instance, properties and construction, it is likely that the CI reflects not only the real linkages, but also the financial channels, as Hong Kong SAR's firms and banks are assumed to be heavily exposed to the developments in China's property markets and construction market. 
Figure 8. Total Connectedness Index by Sectors: China to Hong Kong SAR

16

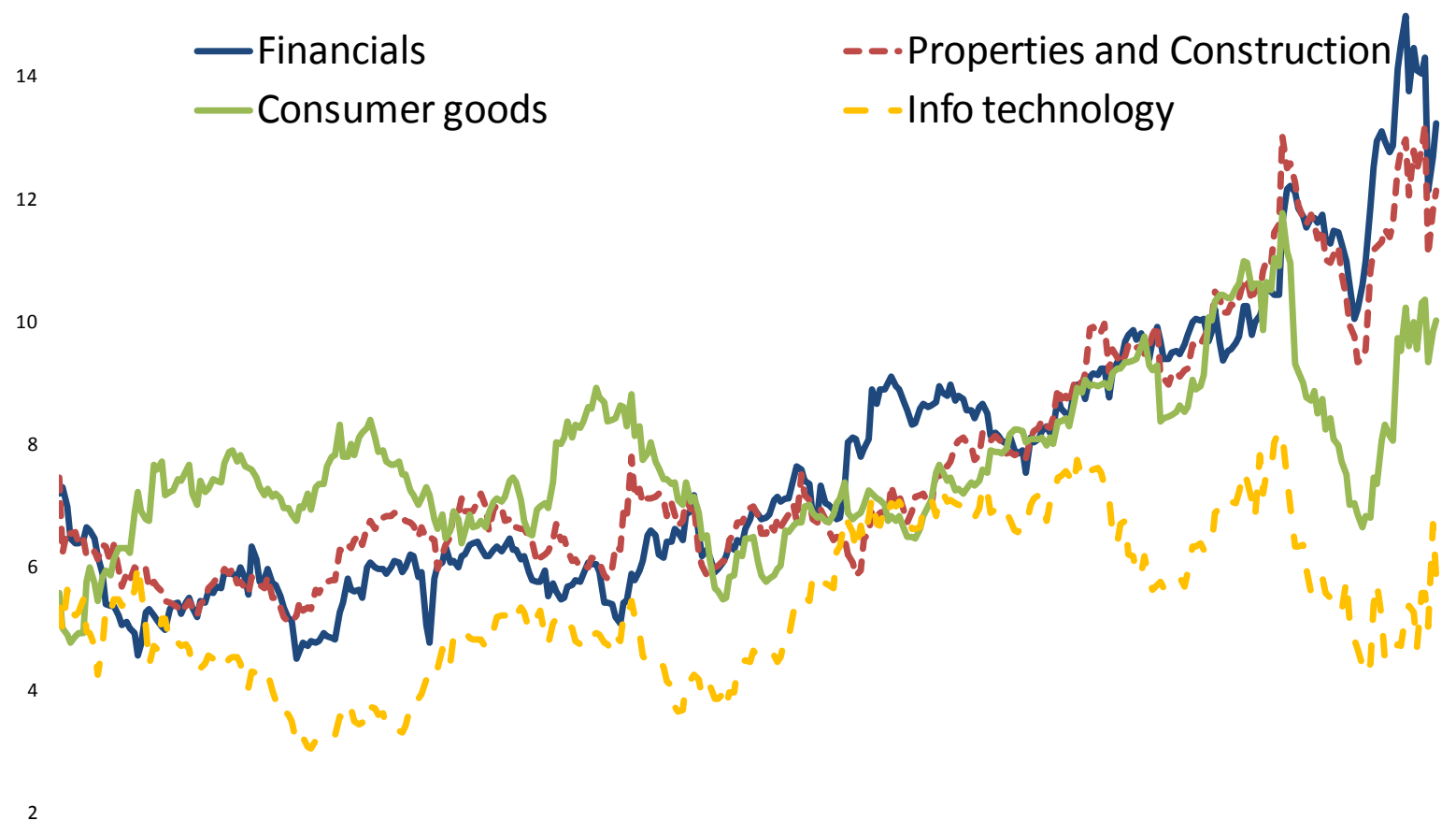

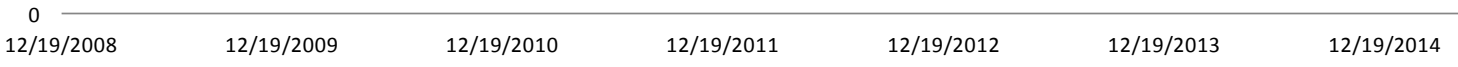

Sources: Haver Analytics and IMF staff calculations

All in all, China's growing importance in the region has been increasingly reflected in financial markets. Hong Kong SAR's financial linkages with mainland China may foreshadow broader linkages with the rest of Asia in the near future. The results here also suggest that financial regulation and supervision should also put a premium on regional interlinkages and better understanding of the gaps in regulation across markets and borders that may give rise to transmission channels for shocks. 


\section{Robustness Checks}

We also ran several checks to assess how robust are our main findings reported above. The first set of robustness checks includes the different windows and lags of the VAR system. As mentioned before, the main results are derived from using four-week lags and 10-week forecast horizons and 100-week for rolling window estimations. Appendix Figure 10 presents the dynamic connectedness index with different windows.

In the second set of robustness checks, we include exogenous variables in the VAR estimation to capture global factors that presumably affect all the markets. Once these global factors are included in the VAR, the connectedness measures can be interpreted as shocks originating from each country, netting out the effects of the shocks driven by common global factors. Some proxies for the global factors that we look into are VIX, Citigroup Economic Surprise Index, Global commodity prices (S\&P GSCI Spot Index), Bloomberg commodity spot index, monthly Global PMI (JP Morgan) and monthly Global PMI Manufacturing only output (JP Morgan). The exogenous factors are entered separately and also jointly in the system for robustness checks. We find that the results are little changed.

\section{CONCLUding REMARKS}

In this paper we apply the connectedness index developed by Diebold and Yilmaz (2009, 2012) to shed light on the nature of financial spillovers and connectedness of Asian equity markets. We find that Asian emerging markets, particularly China, have become important sources of financial shocks that have increasingly large spillovers (as measured by the connectedness index) to other economies, including advanced market economies. This finding highlights the relevance of EM developments to global financial stability and the rise of emerging market economies in the global economy, particularly of Asian economies. China's economy, notwithstanding its recent growth slowdown, best exemplifies this trend as it now accounts for about one-third of global growth, and has become a major player in global trade, and increasingly, global finance.

The growing importance of China as a driver of regional financial market dynamics can also be seen from the changing pattern of the estimated connectedness measure. We show that the financial market developments in China, in particular, already have significant implications for financial markets movements of neighboring economies, particularly Hong Kong SAR. Since the global financial crisis, China has been increasingly a net "giver" of financial shocks to the rest of the Asia-Pacific region. In addition, the ongoing liberalization efforts of China's domestic financial markets and capital controls, as well as the internationalization of the RMB suggest that the importance of China to other Asian markets through financial channels will continue to rise. The rise in intraregional connectedness among the emerging market economies also confirms their role as a net source of shocks, which is expected to grow especially as trade and financial linkages continue to strengthen. 


\section{REFERENCES}

Acharya, V.V., L. Pedersen, T. Phillipe, and M. Richardson (2010), "Measuring Systemic Risk," Manuscript, Stern School, New York University.

Acharya, V. V., L. Pedersen, T. Philippon, and M. Richardson (2009), "Regulating Systemic Risk," Financial Markets, Institutions \& Instruments, 18, 174-175.

Almekinders, G., A. Mourmouras, J. Vichyanond, S. Zhou., and J. Zhou (2015). “ASEAN Financial Integration: Harnessing Benefits and Mitigating Risks," In The Future of Asian Finance, edited by R. Sahay, G. Schiff, C.H. Lim, C. Sumi, and J.P. Walsh. Washington: International Monetary Fund.

Diebold, F. X. and Kamil Yilmaz (2009). 'Measuring Financial Asset Return and Volatility Spillovers, With Application to Global Equity Markets', Economic Journal (119), 158-171.

Diebold, F.X. and Kamil Yilmaz (2010), "Macroeconomic Volatility and Stock Market Volatility, Worldwide," in T. Bollerslev, J. Russell, and M. Watson (eds.), Volatility and Time Series Econometrics: Essays in Hnor of Robert F. Engle, Oxford University Press, New York, 97-116.

Diebold, F. X. and K. Yilmaz (2012), "Better to Give than to Receive: Predictive Measurement of Volatility Spillovers," International Journal of forecasting, 28, 57 66.

Diebold, F.X. and K. Yilmaz (2014), "On the Network Topology of Variance Decompositions: Measuring the Connectedness of Financial Firms," Journal of Econometrics, 182, 119-134.

Forbes, K.J., and R. Rigobon (2002), "No Contagion, Only Interdependence: Measuring Stock Market Comovements," Journal of Finance, 57, 2223-2261.

Glick, R., and M. Hutchinson (2013), "China's Financial Linkages with Asia and the Global Financial Crisis," Federal Reserve Bank of San Francisco Working Paper Series, 2013-12.

Koop, G., M.H. Pesaran, and S.M. Potter (1996), "Impulse Response Analysis in Nonlinear Multivariate Models," Journal of Econometrics, 74, 119-147.

International Monetary Fund. 2014a. Regional Economic Outlook. Asia and Pacific. "Sustaining the Momentum: Vigilance and Reforms." 
International Monetary Fund 2014b. Global Financial Stability Report. "Moving from Liquidity - to Growth-Driven Markets."

International Monetary Fund. 2015. Regional Economic Outlook. Asia and Pacific. "Stabilizing and Outperforming Other Regions."

International Monetary Fund. 2016. Regional Economic Outlook. Asia and Pacific.

Forthcoming.

Pesaran, H.H. and Y. Shin (1998), "Generalized Impulse Response Analysis in Linear Multivariate Models," Economics Letters, 58, 17-29.

Shu, C., D.He, H. Wang and J. Dong (2013), “The Influence of Chinese and US Financial Markets on Asia-Pacific", BIS Papers No. 82. 
Appendix Table 1. Equity Returns Connectedness (Time Period: 06/30/2002-11/01/2015)

\begin{tabular}{|c|c|c|c|c|c|c|c|c|c|c|c|c|c|c|c|c|c|c|c|c|c|c|}
\hline & USA & GBR & EUR & AUS & NZL & JPN & CHN & HKG & KOR & TWN & SGP & PHL & IDN & THA & MYS & IND & BRA & MEX & TUR & ZAF & From Others & Net \\
\hline USA & 0.14 & 0.10 & 0.09 & 0.06 & 0.03 & 0.05 & 0.05 & 0.00 & 0.05 & 0.04 & 0.02 & 0.02 & 0.02 & 0.02 & 0.04 & 0.06 & 0.05 & 0.02 & 0.04 & 0.07 & $86 \%$ & $24 \%$ \\
\hline GBR & 0.09 & 0.13 & 0.10 & 0.07 & 0.03 & 0.06 & 0.05 & 0.00 & 0.05 & 0.04 & 0.02 & 0.03 & 0.03 & 0.02 & 0.03 & 0.05 & 0.06 & 0.03 & 0.04 & 0.06 & $87 \%$ & $30 \%$ \\
\hline EUR & 0.10 & 0.11 & 0.14 & 0.06 & 0.03 & 0.05 & 0.05 & 0.00 & 0.05 & 0.05 & 0.02 & 0.03 & 0.02 & 0.02 & 0.03 & 0.05 & 0.06 & 0.03 & 0.04 & 0.06 & $86 \%$ & $\%$ \\
\hline AUS & 0.07 & 0.08 & 0.06 & 0.14 & 0.05 & 0.06 & 0.06 & 0.00 & 0.06 & 0.05 & 0.03 & 0.04 & 0.03 & 0.03 & 0.04 & 0.04 & 0.06 & 0.02 & 0.04 & 0.05 & $86 \%$ & $20 \%$ \\
\hline NZL & 0.06 & 0.06 & 0.05 & 0.09 & 0.24 & 0.06 & 0.05 & 0.00 & 0.04 & 0.03 & 0.03 & 0.03 & 0.02 & 0.03 & 0.03 & 0.03 & 0.04 & 0.02 & 0.03 & 0.04 & $76 \%$ & $-26 \%$ \\
\hline JPN & 0.06 & 0.06 & 0.05 & 0.06 & 0.03 & 0.13 & 0.05 & 0.01 & 0.08 & 0.05 & 0.04 & 0.05 & 0.04 & 0.04 & 0.05 & 0.04 & 0.04 & 0.03 & 0.05 & 0.05 & $87 \%$ & $27 \%$ \\
\hline CHN & 0.06 & 0.06 & 0.06 & 0.07 & 0.04 & 0.07 & 0.17 & 0.01 & 0.06 & 0.06 & 0.03 & 0.03 & 0.03 & 0.02 & 0.05 & 0.03 & 0.04 & 0.02 & 0.04 & 0.05 & $83 \%$ & $\%$ \\
\hline HKG & 0.03 & 0.02 & 0.03 & 0.02 & 0.01 & 0.04 & 0.02 & 0.50 & 0.06 & 0.03 & 0.02 & 0.03 & 0.02 & 0.03 & 0.03 & 0.03 & 0.02 & 0.01 & 0.02 & 0.02 & $50 \%$ & $-38 \%$ \\
\hline KOR & 0.05 & 0.06 & 0.05 & 0.06 & 0.02 & 0.08 & 0.05 & 0.01 & 0.14 & 0.06 & 0.03 & 0.04 & 0.04 & 0.04 & 0.05 & 0.05 & 0.04 & 0.03 & 0.05 & 0.05 & $86 \%$ & $21 \%$ \\
\hline TWN & 0.05 & 0.05 & 0.05 & 0.05 & 0.02 & 0.06 & 0.06 & 0.01 & 0.06 & 0.15 & 0.03 & 0.04 & 0.04 & 0.03 & 0.07 & 0.05 & 0.05 & 0.03 & 0.04 & 0.05 & $85 \%$ & $7 \%$ \\
\hline SGP & 0.04 & 0.04 & 0.03 & 0.05 & 0.03 & 0.06 & 0.04 & 0.01 & 0.05 & 0.04 & 0.21 & 0.06 & 0.05 & 0.05 & 0.04 & 0.04 & 0.04 & 0.03 & 0.04 & 0.04 & $79 \%$ & $-15 \%$ \\
\hline PHL & 0.04 & 0.04 & 0.03 & 0.05 & 0.02 & 0.07 & 0.04 & 0.01 & 0.06 & 0.05 & 0.06 & 0.18 & 0.05 & 0.05 & 0.04 & 0.04 & 0.04 & 0.02 & 0.05 & 0.04 & $82 \%$ & $-10 \%$ \\
\hline IDN & 0.04 & 0.05 & 0.03 & 0.05 & 0.02 & 0.06 & 0.04 & 0.01 & 0.06 & 0.04 & 0.05 & 0.05 & 0.21 & 0.04 & 0.05 & 0.05 & 0.03 & 0.03 & 0.05 & 0.04 & $79 \%$ & $-15 \%$ \\
\hline THA & 0.04 & 0.04 & 0.03 & 0.05 & 0.03 & 0.08 & 0.03 & 0.01 & 0.06 & 0.05 & 0.05 & 0.06 & 0.04 & 0.21 & 0.05 & 0.04 & 0.03 & 0.02 & 0.04 & 0.04 & $79 \%$ & $-21 \%$ \\
\hline MYS & 0.05 & 0.05 & 0.04 & 0.05 & 0.02 & 0.07 & 0.05 & 0.01 & 0.06 & 0.08 & 0.04 & 0.04 & 0.04 & 0.04 & 0.18 & 0.04 & 0.05 & 0.02 & 0.04 & 0.04 & $82 \%$ & $5 \%$ \\
\hline IND & 0.07 & 0.07 & 0.06 & 0.05 & 0.02 & 0.05 & 0.03 & 0.01 & 0.05 & 0.05 & 0.03 & 0.03 & 0.04 & 0.02 & 0.04 & 0.16 & 0.06 & 0.03 & 0.04 & 0.08 & $84 \%$ & $6 \%$ \\
\hline BRA & 0.06 & 0.08 & 0.06 & 0.07 & 0.03 & 0.05 & 0.04 & 0.00 & 0.05 & 0.05 & 0.03 & 0.03 & 0.03 & 0.02 & 0.04 & 0.06 & 0.16 & 0.02 & 0.04 & 0.06 & $84 \%$ & $0 \%$ \\
\hline MEX & 0.05 & 0.06 & 0.05 & 0.04 & 0.02 & 0.05 & 0.04 & 0.00 & 0.05 & 0.04 & 0.04 & 0.03 & 0.04 & 0.02 & 0.03 & 0.06 & 0.04 & 0.26 & 0.04 & 0.06 & $74 \%$ & $-25 \%$ \\
\hline TUR & 0.05 & 0.06 & 0.05 & 0.05 & 0.02 & 0.07 & 0.04 & 0.00 & 0.07 & 0.05 & 0.03 & 0.04 & 0.04 & 0.03 & 0.04 & 0.05 & 0.04 & 0.03 & 0.17 & 0.05 & $83 \%$ & 6 \\
\hline ZAF & 0.08 & 0.07 & 0.06 & 0.05 & 0.02 & 0.05 & 0.04 & 0.00 & 0.05 & 0.05 & 0.03 & 0.03 & 0.03 & 0.03 & 0.03 & 0.07 & 0.06 & 0.03 & 0.04 & 0.15 & $85 \%$ & $11 \%$ \\
\hline To others & $110 \%$ & $118 \%$ & $99 \%$ & $107 \%$ & $51 \%$ & $114 \%$ & $84 \%$ & $12 \%$ & $108 \%$ & $92 \%$ & $64 \%$ & $72 \%$ & $64 \%$ & $57 \%$ & $78 \%$ & $90 \%$ & $84 \%$ & $49 \%$ & $77 \%$ & $96 \%$ & Total Connectedness & \\
\hline To others including own & $124 \%$ & $130 \%$ & $114 \%$ & $120 \%$ & $74 \%$ & $127 \%$ & $100 \%$ & $62 \%$ & $121 \%$ & $107 \%$ & $85 \%$ & $90 \%$ & $85 \%$ & $79 \%$ & $95 \%$ & $106 \%$ & $100 \%$ & $75 \%$ & $94 \%$ & $111 \%$ & 81.290 & \\
\hline
\end{tabular}

Sources: Haver Analytics and IMF staff calculations 
Appendix Table 2. Equity Volatilities Connectedness (Time Period: 06/30/2002-11/01/2015)

\begin{tabular}{|c|c|c|c|c|c|c|c|c|c|c|c|c|c|c|c|c|c|c|c|c|c|c|}
\hline & USA & GBR & EUR & AUS & NZL & JPN & CHN & HKG & KOR & TWN & SGP & PHL & IDN & THA & MYS & IND & BRA & MEX & TUR & ZAF & From Others & Net \\
\hline USA & 0.20 & 0.11 & 0.08 & 0.06 & 0.06 & 0.06 & 0.02 & 0.01 & 0.05 & 0.03 & 0.01 & 0.02 & 0.02 & 0.02 & 0.04 & 0.08 & 0.05 & 0.02 & 0.01 & 0.06 & $80 \%$ & $31 \%$ \\
\hline GBR & 0.10 & 0.17 & 0.12 & 0.07 & 0.04 & 0.06 & 0.02 & 0.01 & 0.05 & 0.03 & 0.02 & 0.02 & 0.02 & 0.02 & 0.04 & 0.06 & 0.06 & 0.02 & 0.02 & 0.05 & $83 \%$ & $50 \%$ \\
\hline EUR & 0.12 & 0.17 & 0.20 & 0.06 & 0.03 & 0.05 & 0.02 & 0.01 & 0.04 & 0.02 & 0.01 & 0.02 & 0.02 & 0.01 & 0.03 & 0.06 & 0.06 & 0.02 & 0.01 & 0.05 & $80 \%$ & $-1 \%$ \\
\hline AUS & 0.07 & 0.09 & 0.06 & 0.18 & 0.05 & 0.07 & 0.03 & 0.02 & 0.07 & 0.03 & 0.02 & 0.03 & 0.01 & 0.03 & 0.05 & 0.05 & 0.05 & 0.01 & 0.03 & 0.05 & $82 \%$ & $15 \%$ \\
\hline NZL & 0.08 & 0.07 & 0.04 & 0.07 & 0.27 & 0.06 & 0.02 & 0.02 & 0.04 & 0.03 & 0.03 & 0.03 & 0.01 & 0.02 & 0.04 & 0.06 & 0.04 & 0.02 & 0.03 & 0.04 & $73 \%$ & $2 \%$ \\
\hline JPN & 0.07 & 0.07 & 0.04 & 0.05 & 0.04 & 0.16 & 0.02 & 0.01 & 0.07 & 0.05 & 0.03 & 0.04 & 0.02 & 0.04 & 0.05 & 0.05 & 0.05 & 0.02 & 0.04 & 0.05 & $84 \%$ & $-39 \%$ \\
\hline CHN & 0.08 & 0.08 & 0.05 & 0.06 & 0.06 & 0.07 & 0.19 & 0.01 & 0.06 & 0.03 & 0.02 & 0.03 & 0.02 & 0.02 & 0.04 & 0.05 & 0.07 & 0.02 & 0.02 & 0.04 & $81 \%$ & $-32 \%$ \\
\hline HKG & 0.01 & 0.02 & 0.03 & 0.05 & 0.03 & 0.04 & 0.00 & 0.48 & 0.08 & 0.02 & 0.05 & 0.03 & 0.01 & 0.05 & 0.03 & 0.01 & 0.02 & 0.01 & 0.02 & 0.01 & $52 \%$ & $25 \%$ \\
\hline KOR & 0.06 & 0.07 & 0.04 & 0.07 & 0.04 & 0.10 & 0.03 & 0.02 & 0.16 & 0.05 & 0.03 & 0.04 & 0.03 & 0.03 & 0.05 & 0.05 & 0.04 & 0.01 & 0.04 & 0.04 & $84 \%$ & $-9 \%$ \\
\hline TWN & 0.07 & 0.08 & 0.05 & 0.05 & 0.03 & 0.08 & 0.03 & 0.01 & 0.06 & 0.16 & 0.02 & 0.04 & 0.03 & 0.02 & 0.07 & 0.06 & 0.04 & 0.03 & 0.03 & 0.04 & $84 \%$ & $7 \%$ \\
\hline SGP & 0.04 & 0.05 & 0.02 & 0.04 & 0.05 & 0.08 & 0.02 & 0.02 & 0.04 & 0.03 & 0.24 & 0.07 & 0.04 & 0.05 & 0.04 & 0.04 & 0.04 & 0.03 & 0.03 & 0.04 & $76 \%$ & $55 \%$ \\
\hline PHL & 0.04 & 0.06 & 0.03 & 0.04 & 0.04 & 0.08 & 0.02 & 0.01 & 0.05 & 0.05 & 0.06 & 0.20 & 0.04 & 0.05 & 0.05 & 0.04 & 0.05 & 0.03 & 0.04 & 0.04 & $80 \%$ & $-22 \%$ \\
\hline IDN & 0.03 & 0.05 & 0.02 & 0.03 & 0.03 & 0.08 & 0.02 & 0.00 & 0.05 & 0.04 & 0.05 & 0.07 & 0.28 & 0.03 & 0.05 & 0.03 & 0.04 & 0.02 & 0.04 & 0.03 & $72 \%$ & $-6 \%$ \\
\hline THA & 0.03 & 0.04 & 0.02 & 0.03 & 0.02 & 0.10 & 0.02 & 0.02 & 0.06 & 0.05 & 0.05 & 0.06 & 0.03 & 0.28 & 0.06 & 0.04 & 0.03 & 0.02 & 0.04 & 0.04 & $72 \%$ & $-29 \%$ \\
\hline MYS & 0.06 & 0.07 & 0.05 & 0.03 & 0.03 & 0.08 & 0.02 & 0.02 & 0.06 & 0.08 & 0.02 & 0.04 & 0.03 & 0.04 & 0.21 & 0.05 & 0.05 & 0.02 & 0.04 & 0.03 & $79 \%$ & $-17 \%$ \\
\hline IND & 0.10 & 0.08 & 0.05 & 0.04 & 0.05 & 0.06 & 0.01 & 0.01 & 0.05 & 0.04 & 0.02 & 0.03 & 0.02 & 0.02 & 0.04 & 0.21 & 0.06 & 0.02 & 0.02 & 0.08 & $79 \%$ & $-23 \%$ \\
\hline BRA & 0.07 & 0.09 & 0.06 & 0.06 & 0.04 & 0.07 & 0.02 & 0.02 & 0.04 & 0.03 & 0.02 & 0.04 & 0.02 & 0.02 & 0.05 & 0.06 & 0.17 & 0.02 & 0.03 & 0.06 & $83 \%$ & $19 \%$ \\
\hline MEX & 0.04 & 0.07 & 0.05 & 0.04 & 0.03 & 0.07 & 0.02 & 0.00 & 0.03 & 0.05 & 0.03 & 0.05 & 0.02 & 0.03 & 0.04 & 0.04 & 0.05 & 0.28 & 0.03 & 0.02 & $72 \%$ & $5 \%$ \\
\hline TUR & 0.03 & 0.05 & 0.02 & 0.04 & 0.04 & 0.10 & 0.02 & 0.01 & 0.06 & 0.03 & 0.03 & 0.05 & 0.02 & 0.04 & 0.05 & 0.06 & 0.05 & 0.03 & 0.21 & 0.05 & $79 \%$ & $-33 \%$ \\
\hline ZAF & 0.09 & 0.07 & 0.04 & 0.05 & 0.05 & 0.07 & 0.02 & 0.01 & 0.05 & 0.03 & 0.02 & 0.03 & 0.02 & 0.02 & 0.04 & 0.09 & 0.06 & 0.03 & 0.03 & 0.18 & $82 \%$ & $74 \%$ \\
\hline To others & $111 \%$ & $133 \%$ & $79 \%$ & $96 \%$ & $75 \%$ & $45 \%$ & $49 \%$ & $77 \%$ & $75 \%$ & $91 \%$ & $130 \%$ & $58 \%$ & $66 \%$ & $43 \%$ & $62 \%$ & $55 \%$ & $102 \%$ & . & $46 \%$ & $92 \%$ & meclentess & \\
\hline 0 others including own & $131 \%$ & $150 \%$ & $99 \%$ & $115 \%$ & $102 \%$ & $61 \%$ & $68 \%$ & $125 \%$ & $91 \%$ & $107 \%$ & $155 \%$ & $78 \%$ & $94 \%$ & $71 \%$ & $83 \%$ & $77 \%$ & $119 \%$ & $95 \%$ & $67 \%$ & $111 \%$ & 77.778 & \\
\hline
\end{tabular}

Sources: Haver Analytics and IMF staff calculations 
Appendix Figure 3. Dynamic Connectedness (Equity Returns and Volatility) ${ }^{9}$



Sources: Haver Analytics and IMF staff calculations

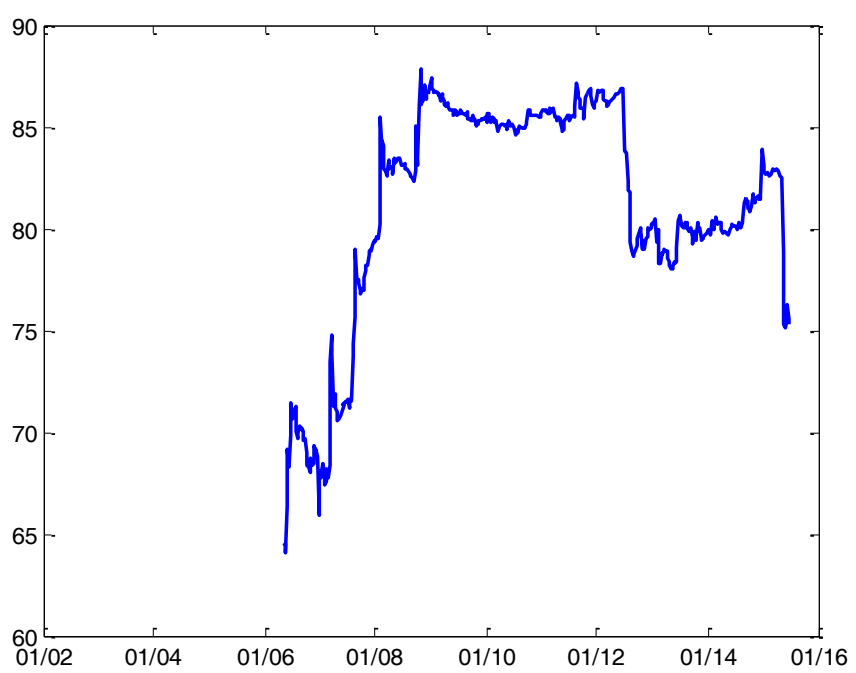

Sources: Haver Analytics and IMF staff calculations

\footnotetext{
${ }^{9}$ Dynamic connectedness index is measured as the rolling window of 200 weeks.
} 


\section{Appendix Figure 4. Dynamic Directional Connectedness of Equity Returns (Contributions to Others)}
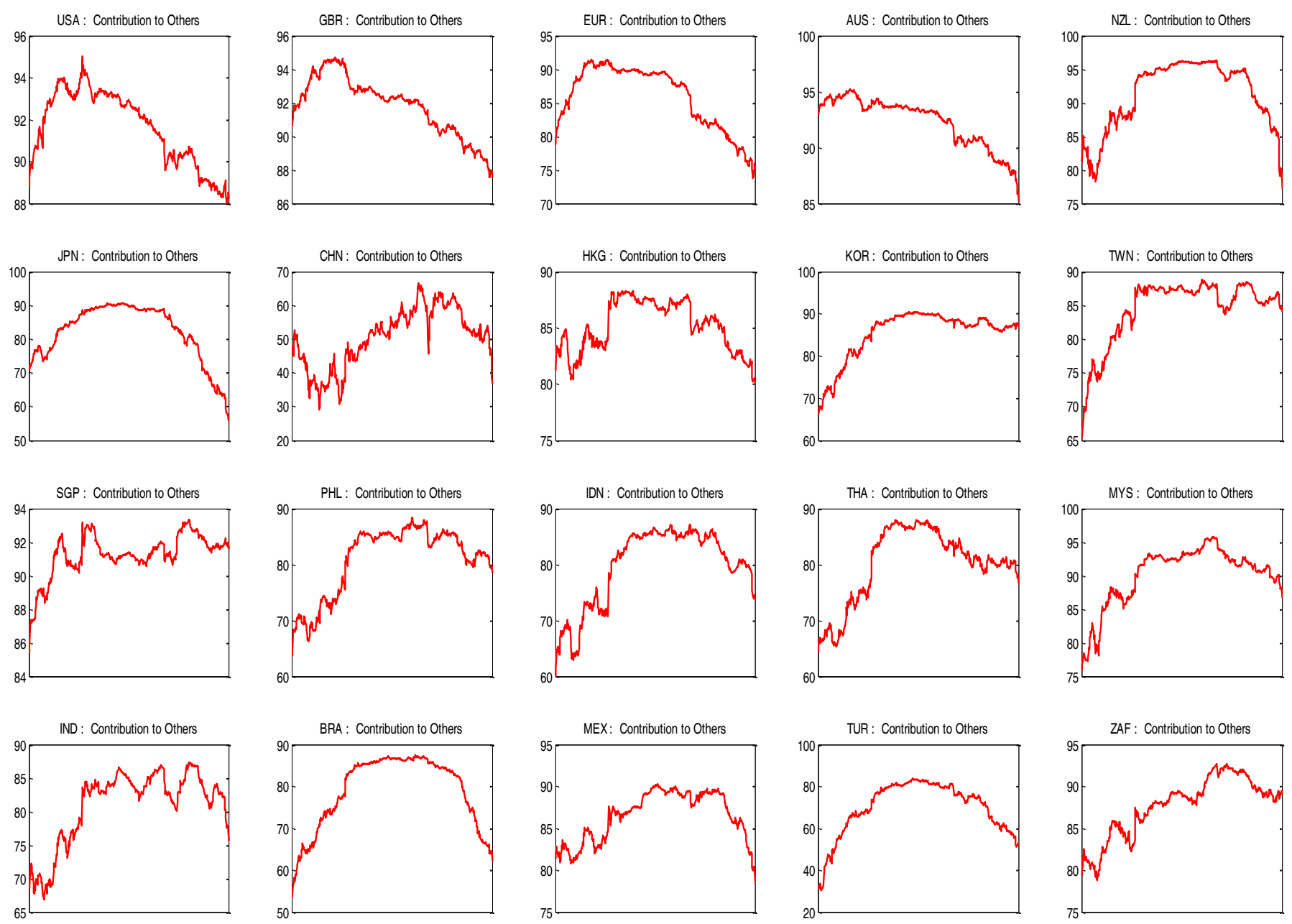

Sources: Haver Analytics and IMF staff calculations 


\section{Appendix Figure 5. Dynamic Directional Connectedness of Equity Volatility (Contributions to Others)}
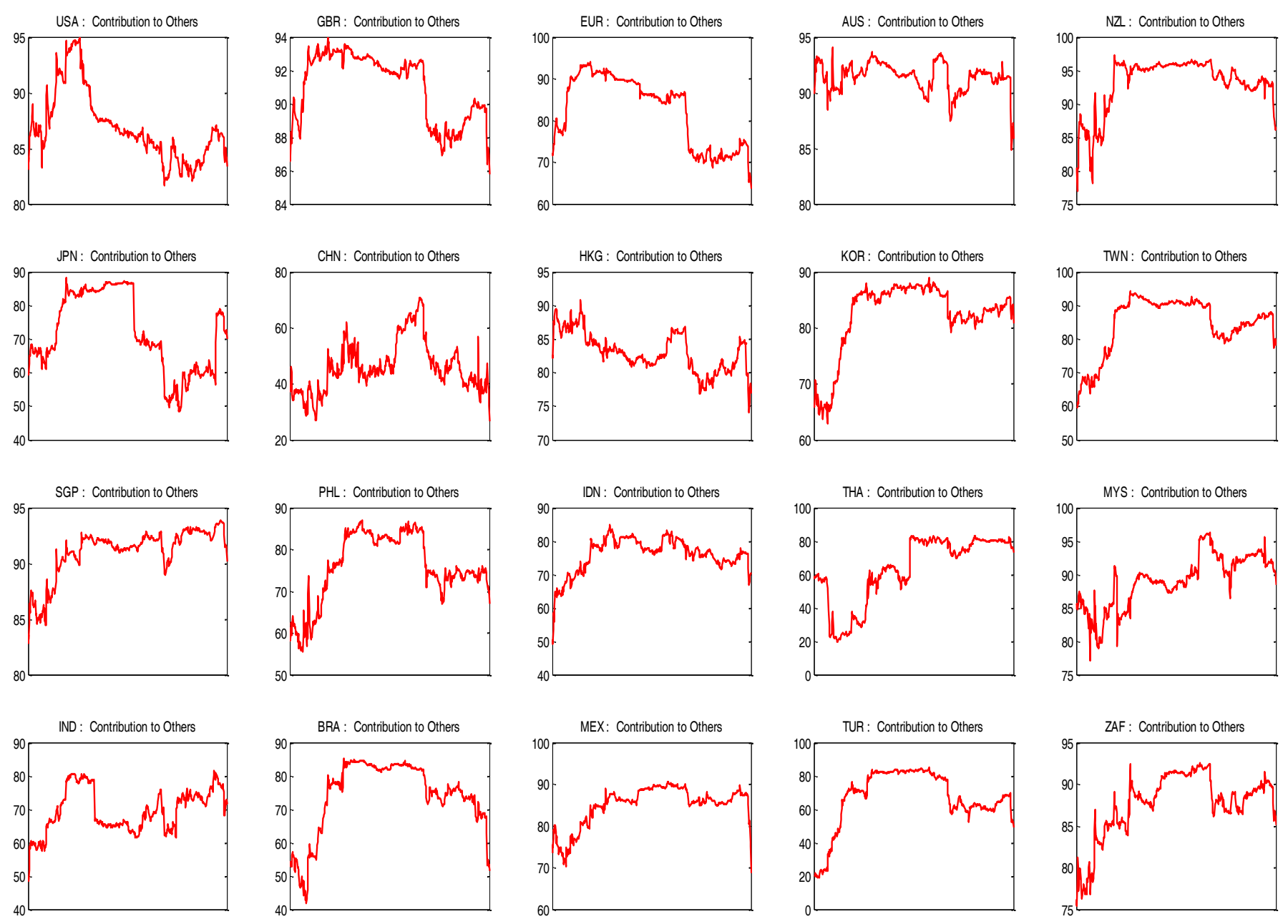


\section{Appendix Figure 6. Dynamic Directional Connectedness of Equity Returns (Contributions from Others)}
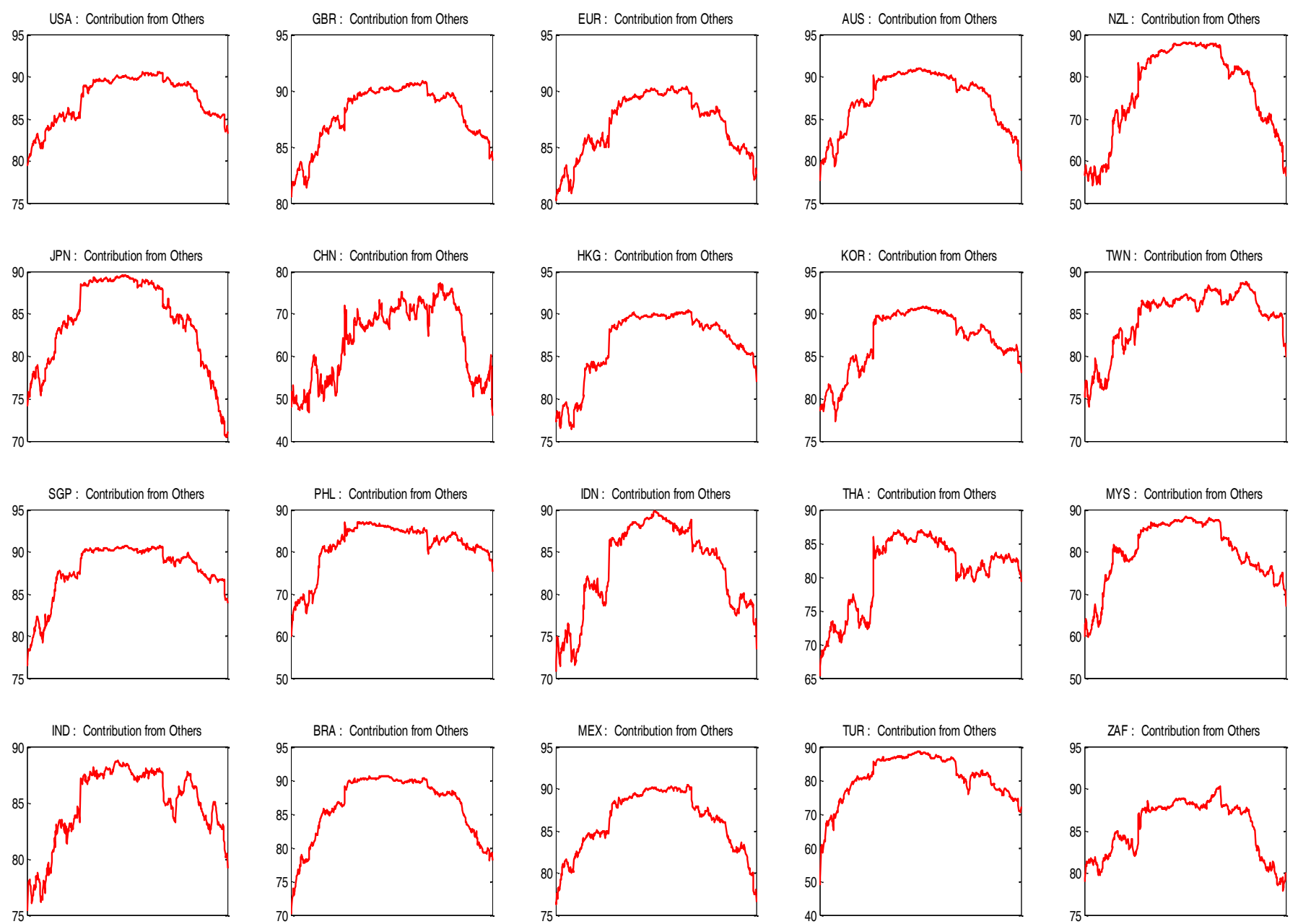

Sources: Haver Analytics and IMF staff calculations 


\section{Appendix Figure 7. Dynamic Directional Connectedness of Equity Volatility (Contributions from Others)}

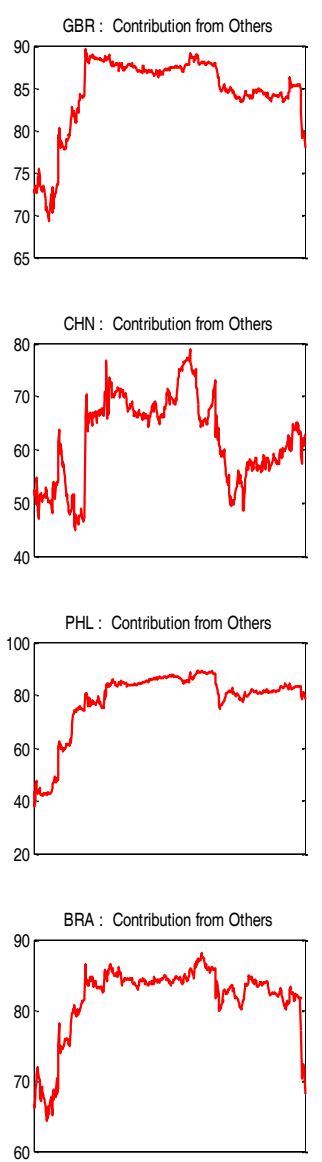
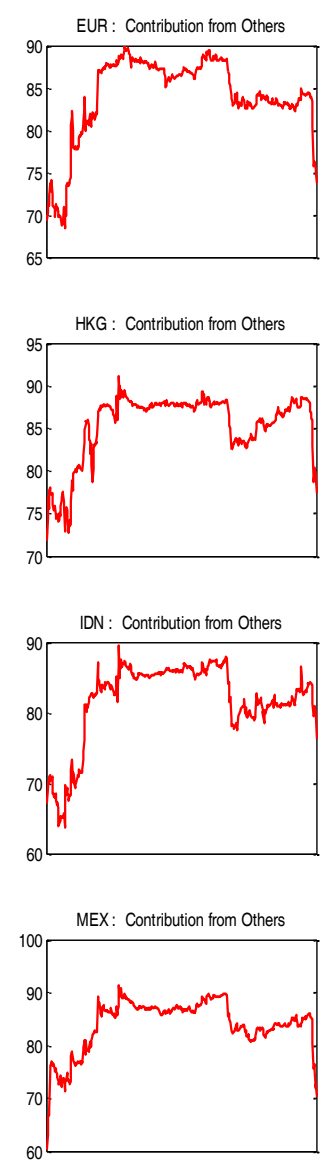
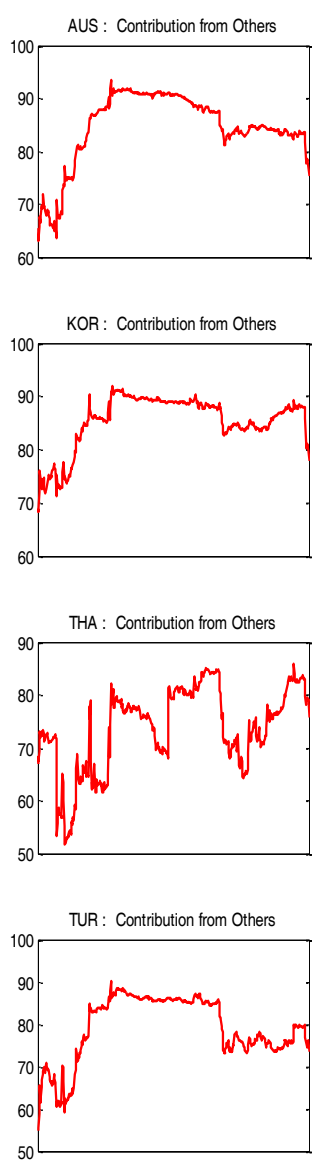
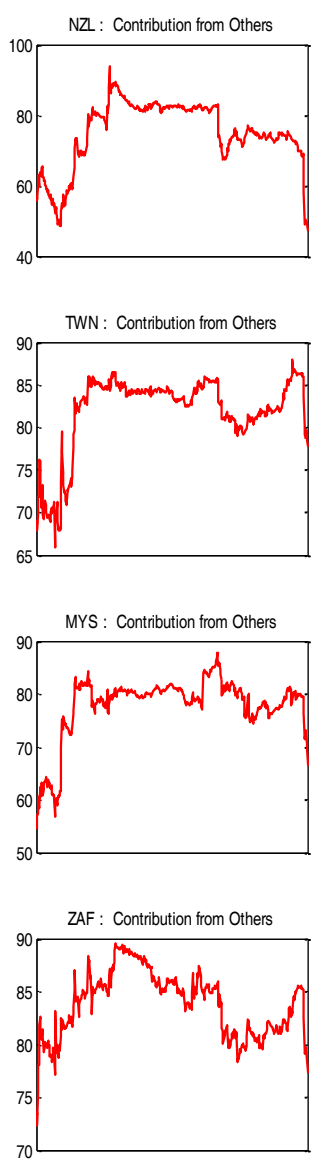

Sources: Haver Analytics and IMF staff calculations 


\section{Appendix Figure 8. Dynamic Net Connectedness of Equity Returns}
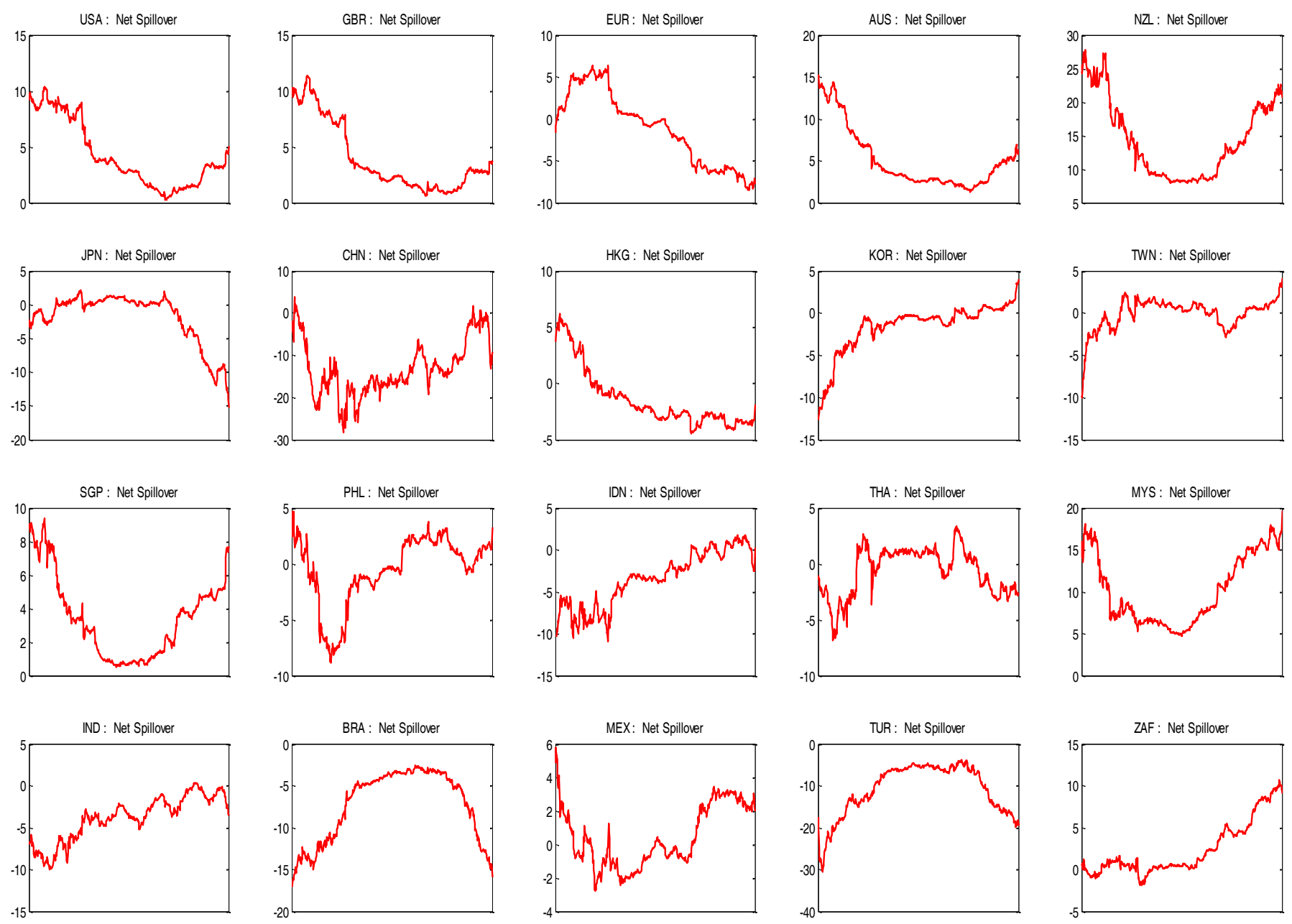

Sources: Haver Analytics and IMF staff calculations 


\section{Appendix Figure 9. Dynamic Net Connectedness of Equity Volatility}
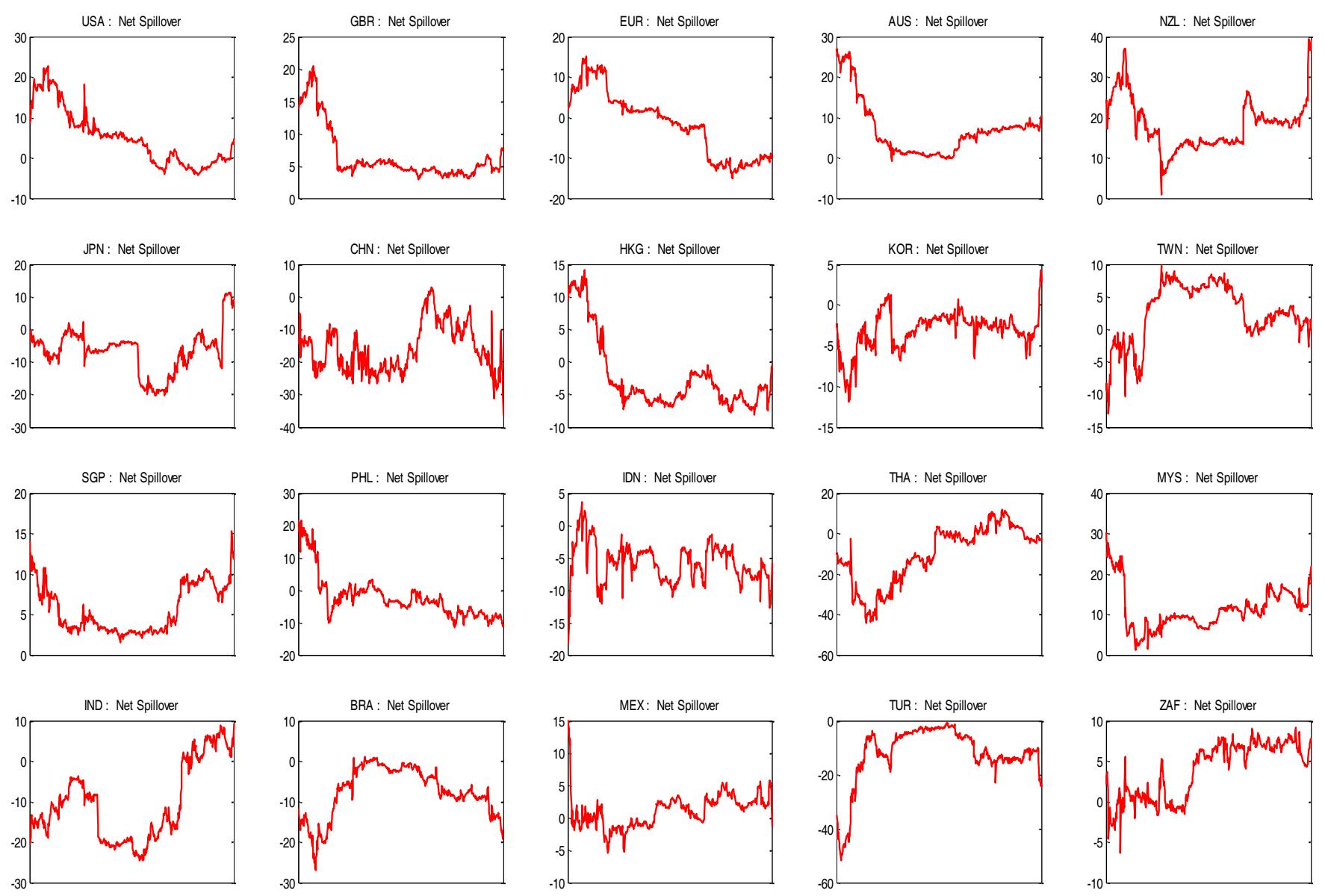

Sources: Haver Analytics and IMF staff calculations 
Appendix Figure 10. Robustness Check: Dynamic Connectedness (Different Forecast Horizons) ${ }^{10}$

\section{Total Connectedness: $\mathrm{H}=\mathbf{1 0}$ weeks}

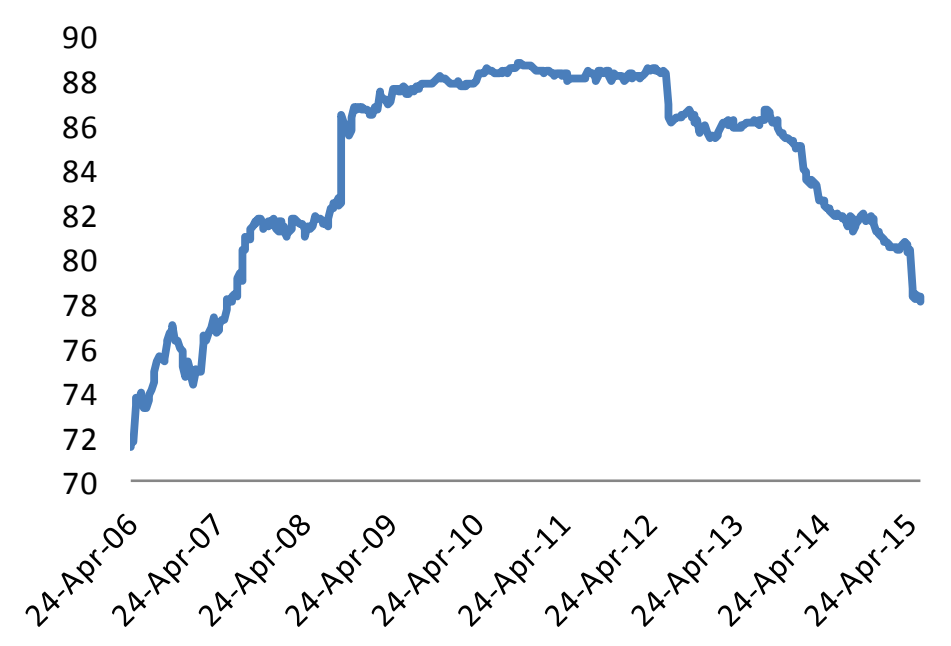

\section{Total Connectedness: $\mathrm{H}=\mathbf{2 0}$ weeks}

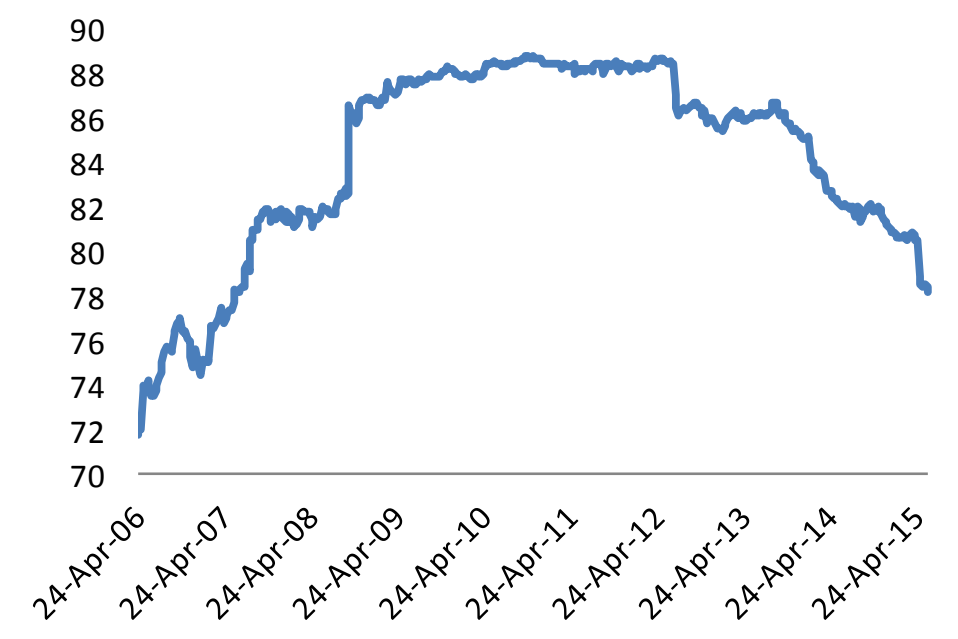

Sources: Haver Analytics and IMF staff calculations

\footnotetext{
${ }^{10}$ Here, we tried different forecast horizons to measure the total connectedness index. H refers to the forecast horizon. The chart on the left is the baseline of 10 weeks. The chart on the right is using 20 weeks as a robustness check.
} 